http://kitaibelia.unideb.hu/

ISSN 2064-4507 (Online) • ISSN 1219-9672 (Print)

(C) Department of Botany, University of Debrecen, Hungary

25(2): 215-238.; 2020

DOI: $10.17542 /$ kit.25.215

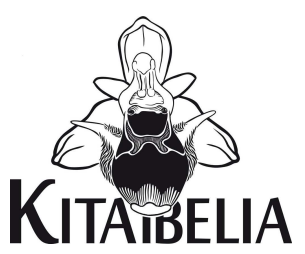

\title{
Feketenyár-ligetek a Dráva mentén (Carduo crispi-Populetum nigrae Kevey in Borhidi \& Kevey 1996)
}

\author{
Kevey Balázs ${ }^{1 *}$ \& CSETE Sándor ${ }^{2}$
}

(1) Pécsi Tudományegyetem, Ökológiai Tanszék, H-7624 Pécs, Ifjúság u. 6.; keveyb@gamma.ttk.pte.hu (2) Szent István Egyetem, Kaposvári Campus, AKK, Környezettudományi és Természetvédelmi Intézet, H-7400 Kaposvár, Guba S. u. 40.

\section{Black poplar riparian forests (Carduo crispi-Populetum nigrae) along the river Drava}

\begin{abstract}
The objective of this study is to analyse the phytosociological characteristics of riverside black poplar forests on the flood plain of the Drava River (southwestern Hungary) by means of 25 relevés. Based on the results of traditional analyses (vegetation structure and attributes of constituent species), their ecological niche and place in plant succession, those streamside forests can be identified with the plant association Carduo crispi-Populetum nigrae described from the Szigetköz region (northwestern Hungary). Stands of this association develop from purple willow scrubs (Rumici crispiSalicetum purpureae), and are located at an elevation about one and a half meters lower than those of its successor vegetation unit, the white poplar association (Senecioni sarracenici-Populetum albae).
\end{abstract}

Keywords: black poplar riparian forests, phytosociological relevé, Southwest Hungary, succession, Syntaxonomy

Összefoglalás - Jelen tanulmány 25 cönológiai felvétellel mutatja be a Dráva hullámterében levő feketenyár-ligetek társulási viszonyait. Szukcessziós és társulástani elemzésre volt szükség a cönoszisztematikai besorolás alátámasztásához. Az állományok a feketenyár dominanciája, a társulás szukcessziós sorban elfoglalt helyzete és a fajcsoportok részletes elemzése alapján a Szigetközből Carduo crispiPopuletum nigrae néven leírt asszociációval azonosíthatók. A csigolyafüzesekből (Rumici crispiSalicetum purpureae) jönnek létre, s mintegy másfél méterrel alacsonyabb szinten találhatók, mint a belőlük fejlődő fehérnyár-ligetek (Senecioni sarracenici-Populetum albae). A sokváltozós eredmények jól mutatják a regionális fajkészletek erőteljes hatását és az egyes társulástípusok pusztán fajösszetétel alapú hasonlósági viszonyait.

Kulcsszavak: Délnyugat-Magyarország, feketenyár-ligeterdő, cönológia, cönológiai felvételek, szukcesszió

\section{Bevezetés}

A hazai feketenyár-ligetekre Kevey Balázs figyelt fel a Szigetközben, s az asszociációt Carduo crispi-Populetum nigrae néven írta le (vö. BoRHIDI \& KEVEY 1996). Később a Szigetköz feketenyár-ligeteiről egy 25 felvételből álló táblázatot is közölt (KEvEY 2008). A későbbi kutatások alatt figyeltünk fel arra, hogy ez az erdőtársulás a Dráva mentén többfelé is megtalálható. Felkeresve ezen állományokat 25 cönológiai felvételt készítettünk azzal a céllal, hogy adatokkal igazoljuk és jellemezzük a társulás itteni előfordulását, hogy összehasonlítsuk a Dráva menti feketenyár-ligeteket a szigetközi felvételekkel, valamint a szukcessziós fejlődési sorozatban a szomszédos fehérnyár-ligetekkel (Senecioni sarracenici-Populetum albae). 


\section{Anyag és módszer}

Kutatási terület jellemzése

Kutatási területünk a Dráva hullámterének Zákány és Drávapalkonya közötti szakasza. A feketenyár-ligetek szórványosan találhatók a Dráva szigetein és partjain, elsősorban olyan kanyarulatokban, ahol a folyó a hordalékát leteríti. Az alapkőzetet folyami kavics és durva homok képezi, amelyen nyers öntéstalaj alakult ki. Az ártéren az első fás társulást a csigolyafüzesek (Rumici crispi-Salicetum purpureae) képezik, amelyek mintegy két évtized alatt feketenyár-ligetekké (Carduo-crispi-Populetum nigrae) fejlődnek. Innen a szukcesszió már lassan játszódik le, míg a magasabb szinteken előbb fehérnyár-ligetek (Senecioni sarraceniciPopuletum albae), majd tölgy-kőris-szil ligetek (Carici brizoidis-Ulmetum) jönnek létre (KEvEY 2016a 2016b) (1. ábra). A feketenyár-ligetek mikroklímája a folyó közelsége miatt hűvös és párás. Meg kell jegyezzük, hogy a Dráva vízjárása különbözik a szigetközi Duna szakasz vízviszonyaitól. A Szigetközben évente párszor a megáradt Duna kilép a medréből, ez az árvíz néhány hétre beboríthatja a hullámteret. A Drávára ezzel szemben nem jellemzőek ezek a nagy árvizek, a puhafás ligeterdők sokkal ritkábban és rövidebb időre kerülnek elárasztásra, mint a Szigetközben. Ezt bizonyítja az, hogy Zákány és Drávatamási között nem volt szükség árvízvédelmi töltés építésére. A 25 cönológiai felvételből csak egyetlen felvétel (Drávapalkonya „Szerb-sziget”) készült hullámtérből, ahol már az árteret az árvízvédelmi töltés hullámtérre és ármentett területre tagolja. Dolgoztunk a folyó bal és jobb partján, magyar és horvát területen egyaránt. A cönológiai felvételeket 96 és 131 m tengerszint feletti magasság között készítettük.

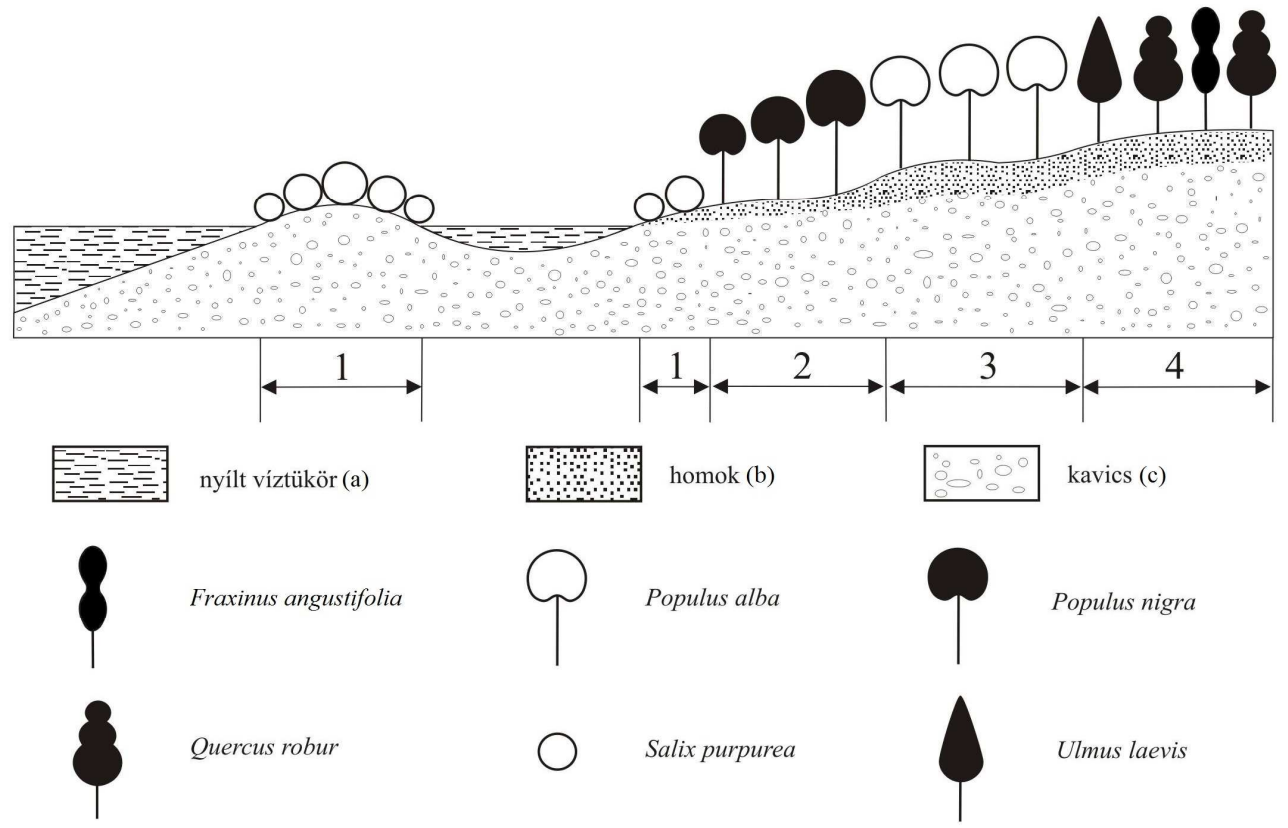

1. ábra Vegetáció-keresztmetszet: Zákány „Sziget”. 1: csigolya bokorfüzes (Rumici crispi-Salicetum purpureae); 2: feketenyár liget (Carduo crispi-Populetum nigrae); 3: fehérnyár liget (Senecioni sarracenici-Populetum albae); 4: tölgy-kőris-szil liget (Carici brizoidis-Ulmetum)

Fig. 1 Vegetation profile from the study area „Sziget” at Zákány village. (a) open water; (b) sand; (c) gravel; 1: purple willow scrub (Rumici crispi-Salicetum purpureae); 2: black poplar gallery forest (Carduo crispi-Populetum nigrae); 3: white poplar gallery forest (Senecioni sarracenici-Populetum albae); 4: oak-ash-elm gallery forest (Carici brizoidis-Ulmetum). 
Alkalmazott módszerek

A cönológiai felvételeket a Zürich-Montpellier növénycönológiai iskola (BECKING 1957; BRAUN-BLANQUET 1964) hagyományos kvadrát-módszerével készítettük. A felvételek táblázatos összeállítását, valamint a karakterfajok csoportrészesedését és csoporttömegét az „NS” számítógépes programcsomag (KEVEY \& HIRMANN 2002) segítségével végeztük. A felvételkészítés és a hagyományos statisztikai számítások módszerét KEVEY (2008) közölte. Az asszociációk összehasonlításánál - a SYN-TAX 2000 programcsomag (PODANI 2001) segítségével bináris adatokon alapuló hierarchikus osztályozást, klaszteranalízist (hasonlósági index: Baroni-Urbani-Buser; osztályozó módszer: teljes lánc), és szintén bináris alapú ordinációt (hasonlósági index: Baroni-Urbani-Buser; ordinációs módszer: főkoordináta-analízis) végeztünk. Az összehasonlító vizsgálatokba belevontuk a Dráva-sík fehérnyár-ligeteiről készült tanulmányt (KEVEY \& TóTH 2006), valamint KEVEY (2008) monográfiáját, amelyekben a szigetközi feketenyár-ligetek és fehérnyár-ligetek felvételei és részletes leírása megtalálható.

A fajok esetében HoRVÁTH et al. (1995), a társulásoknál pedig az újabb hazai nómenklatúrát (BorHIDI \& KEVEY 1996, KEVEY 2008, BorHIDi et al. 2012) követjük. A társulástani és a karakterfaj-statisztikai táblázatok felépítése az újabb eredményekkel (OBERDORFER 1992, Mucina et al. 1993, KeVEY 2008, Borhidi et al. 2012) módosított Soó (1980) féle cönológiai rendszerre épül. A növények cönoszisztematikai besorolásánál is elsősorban Soó (1964, 1966, 1968, 1970, 1973, 1980) Synopsis-ára támaszkodtunk, de figyelembe vettük az újabb kutatási eredményeket is (vö. BoRHIDI 1993, 1995, HoRVÁTH et al. 1995, KEVEY 2008).

\section{Eredmények}

\section{Fiziognómia}

A felső lombkoronaszint közepesen, vagy erősebben zárt, 50-75\% borítást mutat, magassága pedig - az állomány korától függően - 20-28 méter. Az átlagos törzsátmérő ennek megfelelően 35 és $75 \mathrm{~cm}$ között változik. Állandó (K: IV-V) fái a Populus nigra és a Salix alba. Nagyobb tömegben (A-D: 3-4) csak a Populus nigra szokott előfordulni. Az alsó lombkoronaszint igen változó. Borítása 5-50\%, magassága pedig 10-20 m. Állandó (K: IV) fája szintén csak a Populus nigra és a Salix alba. Nagyobb tömegben (A-D: 3) csak a Salix elaeagnos fordul elő az egyik zákányi felvételben. Érdekes továbbá e szintben egyes cserjék fatermetű példányainak (Cornus sanguinea, Crataegus monogyna, Euonymus europaeus), valamint egyes liánok (Clematis vitalba, Hedera helix, Humulus lupulus, Parthenocissus inserta, Vitis vulpina) megjelenése.

A cserjeszint szintén változóan fejlett. Borítása 20-75\%, magassága pedig 2-4 m. Állandó (K: IV-V) fajai a Cornus sanguinea, a Crataegus monogyna és a Sambucus nigra. Jelentősebb tömeget (A-D: 3-4) is csak e három cserjefaj ér el. Az újulat fejlettsége is igen változó, borítása 3-80\%. Állandó (K: IV-V) fajai az alábbiak: Cornus sanguinea, Crataegus monogyna, Euonymus europaeus, Hedera helix, Quercus robur, Rubus caesius. E szintben nagyobb tömeget (A-D: 3-4) csak a Hedera helix és a Rubus caesius képez.

A gyepszint ugyancsak változóan fejlett, borítása 10-85\%. Állandó (K: IV-V) fajai a következők: Aegopodium podagraria, Alliaria petiolata, Angelica sylvestris, Aristolochia clematitis, Brachypodium sylvaticum, Carex acuta, Circaea lutetiana, Cucubalus baccifer, Equisetum hyemale, Galeopsis speciosa, Galium aparine, Glechoma hederacea, Humulus lupulus, Poa trivialis, Solidago gigantea, Symphytum officinale, Torilis japonica, Urtica dioica. Fácies képző (A-D: 3-4) szerepet az Aegopodium podagraria, az Anthriscus cerefolium, a Glechoma hederacea, az Equisetum hyemale, az Impatiens parviflora és a Peucedanum verticillare tölt be (vö. 1. táblázat). 

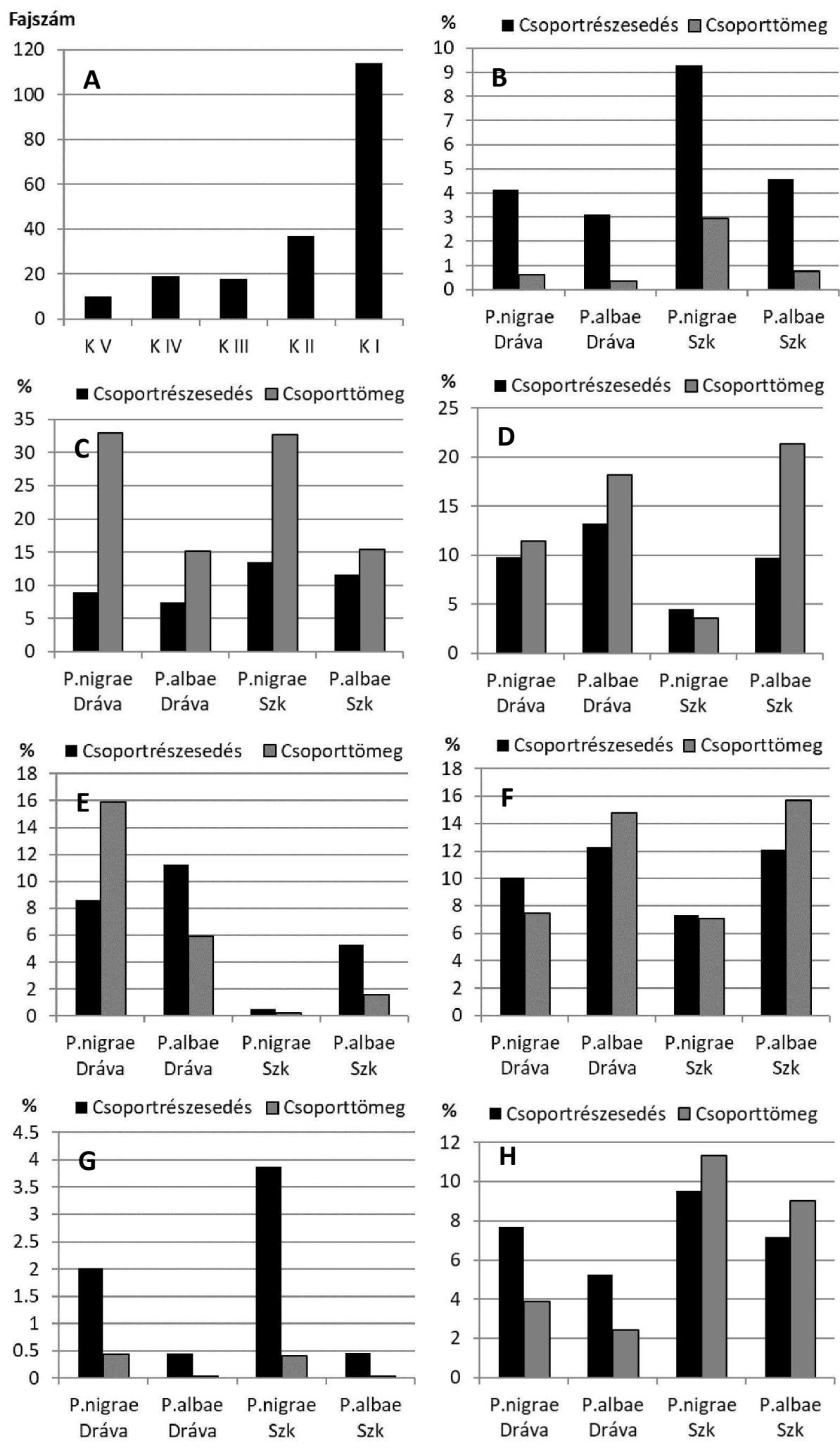
2. ábra A Az állandósági osztályok eloszlása; B Cypero-Phragmitea s.l. fajok aránya; C Salicetea purpureae s.l. fajok aránya; D Querco-Fagetea fajok aránya; E Fagetalia fajok aránya; F Alnion incanae fajok aránya; G Ruderális kompetítorok (RC -2) aránya; H Agresszív tájidegen inváziós fajok (AC -3) aránya

Fig. 2 A Distribution of constancy classes; B Proportion of species diagnostic of the class CyperoPhragmitea s.l.; C Proportion of species diagnostic of the class Salicetea purpureae s.l.; D Proportion of species diagnostic of the class Querco-Fagetea; E Proportion of species diagnostic of the order Fagetalia; F Proportion of species diagnostic of the alliance Alnion incanae s.l.; G Proportion of ruderal competitors (RC -2); H Proportion of invasive species (AC -3)

P.nigrae Dráva: Carduo crispi-Populetum nigrae, Dráva-ártér (Kevey et al. ined.: 25 felv.)

P.albae Dráva: Senecioni sarracenici-Populetum albae, Dráva-ártér (KEVEY \& TóTH 2006: 20 felv.)

P.nigrae Szk: Carduo crispi-Populetum nigrae, Szigetköz (Kevey 2008: 25 felv.)

P.albae Szk: Senecioni sarracenici-Populetum albae, Szigetköz (Kevey 2008: 25 felv.)

\section{Fajkombináció}

\section{Állandósági osztályok}

A 25 cönológiai felvétel alapján a vizsgált feketenyár-ligetekből 10 konstans (K V) és 19 szubkonstans (K IV) faj szerepel az alábbiak szerint: - K V: Cornus sanguinea, Galium aparine, Glechoma hederacea, Hedera helix, Humulus lupulus, Populus nigra, Rubus caesius, Salix alba, Solidago gigantea, Symphytum officinale. - K IV: Aegopodium podagraria, Alliaria petiolata, Angelica sylvestris, Aristolochia clematitis, Brachypodium sylvaticum, Carex acuta, Circaea lutetiana, Crataegus monogyna, Cucubalus baccifer, Equisetum hyemale, Euonymus europaeus, Galeopsis speciosa, Ligustrum vulgare, Poa trivialis, Quercus robur, Sambucus nigra, Torilis japonica, Ulmus laevis, Urtica dioica. A felvételi anyagban ezen kívül 18 akcesszórikus (K III), 37 szubakcesszórikus (K II) és 114 akcidens (K I) faj is szerepel. Az állandósági osztályok fajszáma tehát az akcidens (K I) elemektől szinte fokozatosan csökken, csupán a szubkonstans fajoknál van egy igen enyhe kiemelkedés (vö. 2. ábra A; 1. táblázat).

\section{Karakterfajok aránya}

A karakterfaj-statisztikai vizsgálatok szerint a feketenyár-ligetekben (Carduo crispiPopuletum nigrae) magasabb arányt mutatnak a mocsári (Cypero-Phragmitea s.l.) és a puhafás ligeterdei (Salicetea purpureae s.l.) növények, mint a fehérnyár-ligetekben (Senecioni sarracenici-Populetum nigrae). E növények a Szigetközben gyakoribbak, mint a Dráva mentén (4. táblázat; 2. ábra B-C). Ennek ellenkezőjét tapasztaljuk a mezofil jellegű szüntaxonok esetében, ugyanis a Querco-Fagetea, a Fagetalia és az Alnion incanae fajok a fehérnyárligetekben (Senecioni sarracenici-Populetum albae) érnek el magasabb arányt. Ezek a fajok a Dráva mentén gyakoribbak, mint a Szigetközben (4. táblázat; 2. ábra D-F).

\section{Szociális magatartási típusok aránya}

A szociális magatartási típusok közül elsősorban a ruderális kompetítorokra (RC -2) érdemes odafigyelni, amelyek mind a Dráva mentén, mind pedig a Szigetközben a feketenyárligetekben (Carduo crispi-Populetum nigrae) magasabb arányt mutatnak, mint a fehérnyárléigetekben (Senecioni sarracenici-Populetum albae) (6. táblázat; 2. ábra G). Hasonló arányokat látunk az agresszív tájidegen kompetítorok ( $\mathrm{AC}$-3) esetében is (6. táblázat; 2. ábra $\mathrm{H}$ ). 


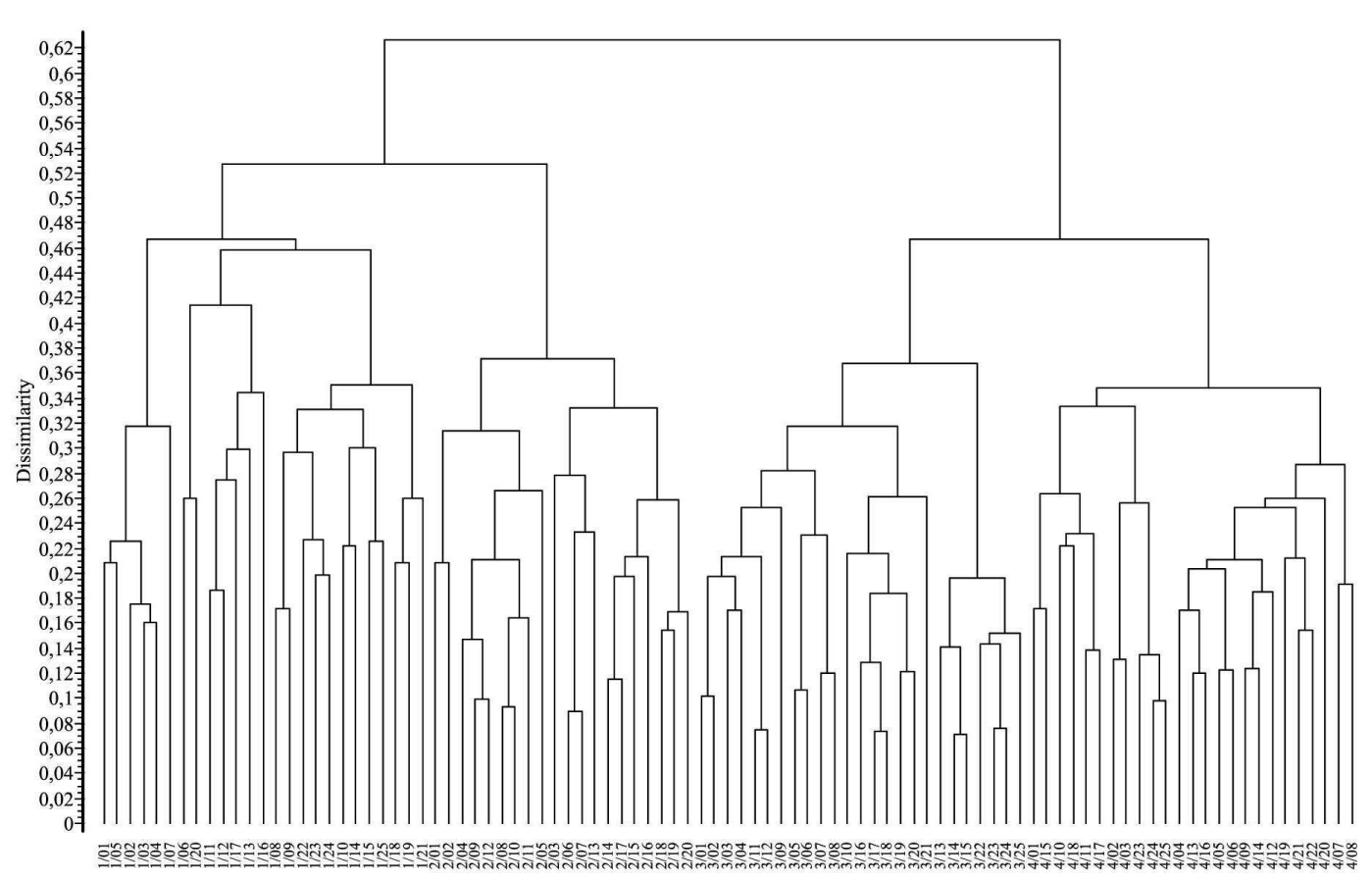

3. ábra Cönológiai felvételek bináris dendrogramja

(hasonlósági index: Baroni-Urbani - Buser; osztályozó módszer: teljes lánc)

Fig. 3 Binary dendrogram of relevés

(similarity coefficient: Baroni-Urbani - Buser; clustering method: complete link)

1/1-25: Carduo crispi-Populetum nigrae, Dráva-ártér (Kevey et al. ined.)

2/1-20: Senecioni sarracenici-Populetum albae, Dráva-ártér (KEVEY \& TóTH 2006)

3/1-25: Carduo crispi-Populetum nigrae, Szigetköz (Kevey 2008)

4/1-25: Senecioni sarracenici-Populetum albae, Szigetköz (KeVEY 2008)

\section{Sokváltozós elemzések eredményei}

A Dráva-ártér és a Szigetköz nyárligeteit (Carduo crispi-Populetum nigrae, Senecioni sarracenici-Populetum albae) bináris klaszteranalízis és ordináció révén hasonlítottuk össze. A dendrogramon (3. ábra) és az ordinációs diagramokon (4. ábra) a feketenyár- és fehérnyárligetek elkülönültek, bár ez az elkülönülés a Szigetközben tökéletesebb, mint a Drávaártéren. Feltűnő viszont, hogy a választott elemző módszer alapján a regionális hasonlóságok nagyobbaknak látszanak, mint a társulástaniak. A Dráva menti feketenyár-ligetek nem a Szigetközi feketenyár-ligetekkel, hanem a Dráva menti fehérnyár-ligetekkel kapcsolódnak (3. ábra). Ugyanez a jelenség látszik az ordinációs ábrán is (4. ábra). Mindezek oka, hogy a bináris adatokon alapuló hasonlósági index a fajösszetételt helyezi előtérbe, szemben más szempontokkal.

\section{Természetvédelmi vonatkozások}

A Dráva feketenyár-ligetei (Carduo crispi-Populetum nigrae) - a horvátországi állományok kivételével - a Duna-Dráva Nemzeti Park területén találhatóak. Természetvédelmi szempontból értékes foltokat képeznek, ugyanis a hazánkban bizonyítottan másutt csak a Szigetközben található ez az erdőtársulás (KEVEY 2008). 


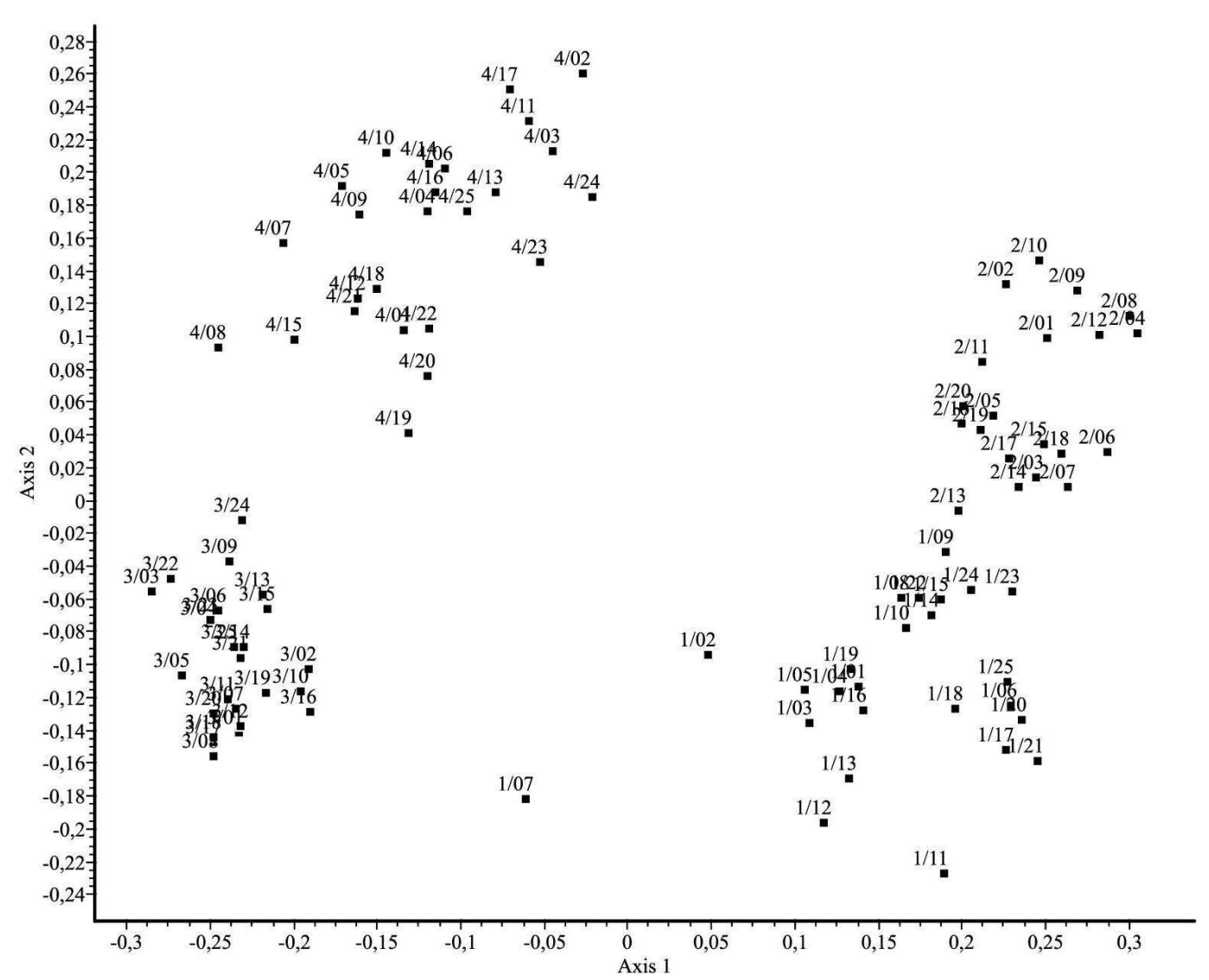

4. ábra Cönológiai felvételek bináris ordinációs diagramja

(hasonlósági index: Baroni-Urbani - Buser; ordinációs módszer: főkoordináta analízis)

Fig. 4 Binary ordination diagram of relevés

(similarity coefficient: Baroni-Urbani-Buser; ordination method: principal coordinates analysis)

1/1-25: Carduo crispi-Populetum nigrae, Dráva-ártér (Kevey et al. ined.)

2/1-20: Senecioni sarracenici-Populetum albae, Dráva-ártér (KeveY \& TóTH 2006)

3/1-25: Carduo crispi-Populetum nigrae, Szigetköz (Kevey 2008)

4/1-25: Senecioni sarracenici-Populetum albae, Szigetköz (KeVEY 2008)

A vizsgált feketenyár-ligetekből 12 védett növényfaj került elő: K IV: Equisetum hyemale. - K III: Peucedanum verticillare. - K II: Carpesium abrotanoides, Salix elaeagnos. - K I: Cephalanthera longifolia, Dryopteris carthusiana, Galanthus nivalis, Leucojum aestivum, Myricaria germanica, Omphalodes scorpioides, Ophioglossum vulgatum, Orchis militaris. E növények közül különösen a Peucedanum verticillare, a Salix elaeagnos és a Myricaria germanica előfordulása jelentős.

Az asszociáció dendrológiai értékeihez tartoznak olyan Populus nigra egyedek, amelyek mellmagasságban mért törzsátmérője elérheti az 1,5-2 m-t is. Akadnak közöttük olyan példányok is, amelyek törzse hatfelé ágazik. A dendrológiai ritkaságok közé sorolhatók a fává nőtt cserjék is (Cornus sanguinea, Crataegus monogyna, Euonymus europaeus), amelyek elérhetik a $40 \mathrm{~cm}$-es törzsátmérőt.

Flóraszennyező hatást fejtenek ki a felvételekben is szereplő egyes adventív növényfajok: K V: Solidago gigantea. - K III: Erigeron annuus, Impatiens glandulifera, Morus alba. - K II: Acer negundo, Amorpha fruticosa, Aster $\times$ salignus, Fraxinus pennsylvanica, Impatiens parviflo- 
ra, Robinia pseudo-acacia, Vitis vulpina. - K I: Ailanthus altissima, Celtis occidentalis, Conyza canadensis, Echinocystis lobata, Juglans regia, Oxalis stricta, Parthenocissus inserta, Phytolacca americana, Pinus sylvestris, Rudbeckia laciniata. Közülük különösen aggasztó az Acer negundo, az Amorpha fruticosa, az Aster $\times$ salignus, a Fraxinus pennsylvanica, az Impatiens glandulifera, a Solidago gigantea, és a Vitis vulpina agresszív terjeszkedése.

\section{Eredmények megvitatása}

Ismereteink szerint tipikus feketenyár-ligetek (Carduo crispi-Populetum nigrae) olyan folyószakaszokon szoktak kialakulni, ahol a folyami hordalék elsősorban kavics. E társulást Magyarországon eddig csak a Szigetközből és a Dráva mellől sikerült kimutatni. Az elemzési eredmények szerint e két táj feketenyár-ligetei között azonban van némi különbség. A Dráva menti feketenyár-ligeteknek ugyanis van egy - a szigetköziektől eltérő - sajátos arculata, amit az Equisetum hyemale tömeges előfordulása, a Carpesium abrotanoides, az Oenanthe banatica, a Peucedanum verticillare és a Salix elaeagnos szórványos megjelenése, valamint a Myricaria germanica ritka előfordulása kölcsönöz. Ugyanakkor a Dráva mentén nem került elő a szigetközi feketenyár-ligetekben gyakori Carduus crispus és Senecio sarracenicus, továbbá a szórványos Ribes nigrum, valamint a ritka Stellaria nemorum (vö. Kevey 2008).

Feltűnő, hogy a feketenyár-ligetek (Carduo crispi-Populetum nigrae) közül a Dráva mentén kisebb a Cypero-Phragmitea s.l. és a Salicetea purpureae s.l. elemek aránya, mint a Szigetközben (4. táblázat; 3-4. ábra). Ezzel szemben a mezofil jellegú szüntaxonok a Dráva menti állományokban gyakoribbak (4. táblázat; 5-7. ábra). Ennek magyarázata abban rejlik, hogy a Dráva mentén sokkal ritkábbak a nagy árvizek, mint a Szigetközben (a Duna szlovákiai elterelése előtt!), a feketenyár-ligetek ezért ritkábban és rövidebb időre kerülnek itt elárasztásra.

A sokváltozós elemzéseknél a várt eredménnyel ellentétben a Dráva menti feketenyárligetek (Carduo crispi-Populetum nigrae) nem a szigetközi feketenyár-ligetekkel, hanem a Dráva menti fehérnyár-ligetekkel (Senecioni sarracenici-Populetum albae) kapcsolódnak (10. ábra). Ugyanez mondható el a Szigetközről is, amelynek feketenyár-ligetei a szigetközi fehérnyár-ligetekkel kapcsolódnak. Ennek magyarázata szintén az lehet, hogy a Dráva és a Szigetköz hullámterének ár-apály viszonyai jelentős mértékben különböznek (lásd előbb a „Kutatási terület jellemzése" cím alatt). Mivel a Dráva mentén a puhafás ligeterdők ritkábban és rövidebb időre kerülnek elárasztásra, ezért mind a feketenyár-ligetek és mind a fehérnyárligetek szukcessziója előbbre van, mint a Szigetközben, amit elsősorban a Fagetalia fajok (pl. Aegopodium podagraria, Arum maculatum, Asarum europaeum, Circaea lutetiana, Corydalis cava, Dryopteris filix-mas, Hedera helix, Galanthus nivalis, Galium odoratum, Moehringia trinervia, Sanicula europaea stb.) viszonylag nagyobb aránya juttat kifejezésre (4. táblázat). E hidrológiai viszonyokkal kapcsolatos az is, hogy a Dráva melletti fekete- és fehérnyárligetekben kevesebb a higrofil jellegü növény (pl. Cypero-Phragmitea s.l., Salicetea purpureae s.l.) és több a mezofil jellegú elem (Querco-Fagetea, Fagetalia, Alnion incanae s.l.), mint a Szigetközben (3-7. ábra). Mivel az alkalmazott hasonlósági index (Baroni-Urbani - Buser) fajösszetétel-hasonlóságot vizsgál, már pedig a regionális fajkészletek a Dráva menti feketenyár-ligetek és fehérnyár-ligetek között jobban hasonlítanak egymásra, mint a Dráva menti és a szigetközi feketenyár-ligetek esetében. Az összehasonlító anyagban szereplő asszociációk ezért nem a vártnak megfelelően kapcsolódnak egymással (10. ábra).

A feketenyár-ligetekből (Carduo crispi-Populetum nigrae) fejlődnek a fehérnyár-ligetek (Senecioni sarracenici-Populetum albae). E két asszociáció közötti szukcessziós kapcsolatot KEVEY (2008, 2016a, 2016b) részletesen jellemezte. Mivel a feketenyár-ligetek alacsonyabb ártéri szinten találhatók, mint a fehérnyár-ligetek, a karakterfajok aránya is ennek megfele- 
lően alakult. Így a Cypero-Phragmitea s.l. és a Salicetea purpureae s.l. elemek a feketenyárligetekben gyakoribbak (4. táblázat; 3-4. ábra), a Querco-Fagetea, a Fagetalia és az Alnion incanae jellegű fajok pedig a fehérnyár-ligetekben mutatnak magasabb arányt (4. táblázat; 57. ábra). A két asszociáció közötti különbséget a differenciális fajok is megerősítik (7. táblázat).
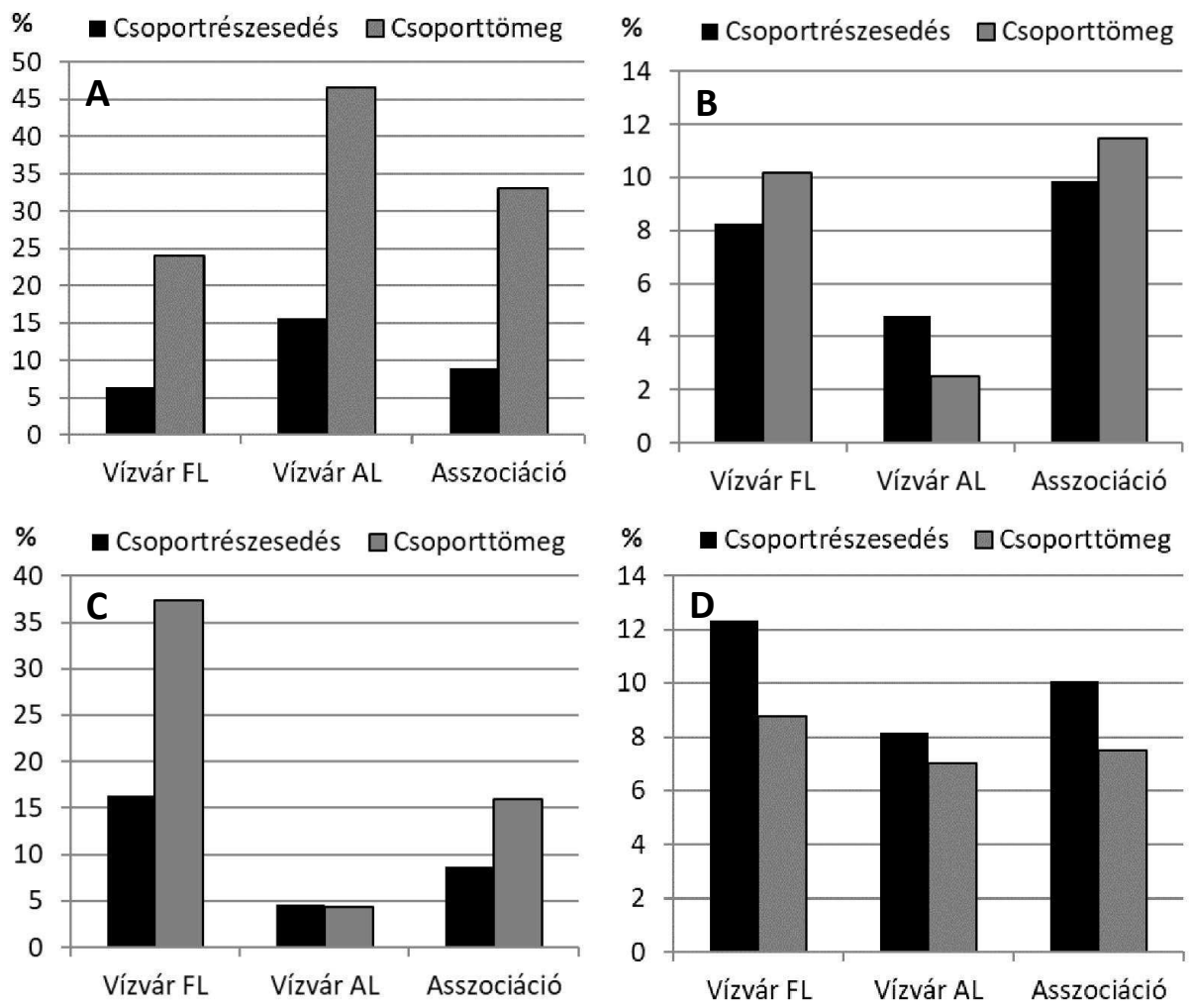

5. ábra A Salicetea purpureae s.l. fajok aránya; B Querco-Fagetea fajok aránya; C Fagetalia fajok aránya; D Alnion incanae fajok aránya

Fig. 5 A Proportion of species diagnostic of the class Salicetea purpureae s.l.; B Proportion of species diagnostic of the class Querco-Fagetea; C Proportion of species diagnostic of the order Fagetalia; D Proportion of species diagnostic of the alliance Alnion incanae s.l.

Vízvár FL: Carduo crispi-Populetum nigrae, Vízvár „Felső-Lóka” (Kevey ined.: 1 felv.) Vízvár AL: Carduo crispi-Populetum nigrae, Vízvár „Alsó-Lóka” (Kevey ined.: 1 felv.)

A két asszociáció közötti átalakulási folyamatra alább egy jó példát tudunk bemutatni. Már a felvételek készítése közben is felfigyeltünk arra, hogy a feketenyár-ligetek egyes állományai között viszonylag nagyok a különbségek. Vannak ugyanis fiatalabb és idősebb feketenyár-ligetek. Előbbiek alacsonyabb, utóbbiak magasabb ártéri szinten helyezkednek el. Ennek dokumentálására kiválasztottunk két - viszonylag egymáshoz közeli - felvételt: Vízvár „Felső-Lóka” (112 m) és Vízvár „Alsó-Lóka” (108 m). Felső-Lókánál a mintaterületen több olyan fajt is találtunk, amelyeket inkább a fehérnyár-ligetekben (Senecioni sarraceniciPopuletum albae), vagy akár a tölgy-kőris-szil ligetekben (Carici brizoidis-Ulmetum) tudtunk volna elképzelni: Acer pseudoplatanus, Ajuga reptans, Asarum europaeum, Carex sylvatica, Carpinus betulus, Cerasus avium, Dryopteris filix-mas, Paris quadrifolia, Sanicula europaea, Viola reichenbachiana. E növények egyike sem fordult elő az Alsó-Lókánál készített felvétel- 
ben, ahol viszont olyan fajokat találtunk, amelyek a társulás mélyebb ártéri szinten való előfordulására utalnak: Bidens tripartita, Calystegia sepium, Cucubalus baccifer, Humulus lupulus, Leucojum aestivum, Myosotis scorpioides, Persicaria dubia, Persicaria hydropiper, Phalaris arundinacea, Phragmites australis, Rorippa palustris, Rumex obtusifolius, Salix alba, Salix elaeagnos, Salix purpurea, Scutellaria galericulata (1-3. táblázat). Már ezek az adatok sejtetik, hogy a két felvétel között viszonylag nagyobb különbség van. Elvégezve a karakterfajstatisztikai számításokat, egyes fontosabb paraméterek esetében kétszeres, sőt, háromszoros különbségeket is kaptunk (5. táblázat; 5. ábra). Ebből azt a következtetést vonhatjuk le, hogy a Vízvár „Felső-Lóka” felvétel a szukcesszió során már annyira előrehaladt stádiumba érkezett, ahol az aljnövényzet faji összetétele már beillik a fehérnyár-ligetek (Senecioni sarracenici-Populetum albae) sorába, a lombkoronaszint viszont még nem cserélődött le. A Vízvár „Alsó-Lóka” felvétel ezzel szemben még magán viseli szukcessziós múltjának, azaz a csigolyafüzesek (Rumici crispi-Salicetum purpureae) jegyeit.

A kisebb-nagyobb különbségek ellenére a Dráva melletti feketenyár-ligeteket a Szigetközből leírt Carduo crispi-Populetum nigrae asszociációval azonosíthatjuk, mivel a feketenyár dominanciája és a társulás szukcessziós sorban elfoglalt helyzete ezt indokolttá teszi. A névadó Carduus crispus a Dráva mentén a felmérések során ugyan nem került elő, ezért a társulás neve jelen esetben szimbolikusnak tekinthető. Az asszociáció cönoszisztematikai helye az alábbi módon vázolható:

Divisio: Querco-Fagea 1967

Classis: Salicetea purpureae Moor 1958

Ordo: Salicetalia purpureae MooR 1958

Alliance: Salicion albae Soó 1930

Suballiance: Populenion nigro-albae KevEY 2008

Associatio: Carduo cirspi-Populetum nigrae KeVEY in BoRHIDI et KevEY 1996

\section{Köszönetnyilvánítás}

Az országhatár és a folyón való átkelés sokfelé megnehezítette a munkánkat. Gyakran a Duna-Dráva Nemzeti Park természetvédelmi őrei segítették munkánkat úgy, hogy motorcsónakkal sikerült megközelíteni a mintaterületeket. Így köszönetünk illeti Csór Sándor és Fenyősi László őröket, valamint Toldi Miklós† amatőr természetvédőt. Köszönetünket fejezzük ki Horváth Ferenc, Juhász Magdolna és Lendvai Gábor kollégáinknak is, javító szándékú megjegyzéseikért.

\section{Rövidítések}

A1: felső lombkoronaszint; A2: alsó lombkoronaszint; Adv: Adventiva; AF: Aremonio-Fagion; Agi: Alnenion glutinosae-incanae; Ai: Alnion incanae; Alo: Alopecurion pratensis; AlS: Alysso-Sedion; Aon: Alnion glutinosae; APa: Abieti-Piceea; Aph: Aphanion; AQ: Aceri tatarici-Quercion; AR: AgropyroRumicion crispi; Ara: Arrhenatheretalia; Arc: Arction lappae; Arn: Arrhenatherion elatioris; Ata: Alnetalia glutinosae; B1: cserjeszint; B2: újulat; Bia: Bidentetalia; Bon: Bidention tripartiti; C: gyepszint; CG: Calluno-Genistion; Cgr: Caricenion gracilis; Che: Chenopodietea; ChS: Chenopodio-Scleranthea; Cia: Calystegietalia sepium; Cn: Calystegion sepium; Cp: Carpinenion betuli; CyF: Cynodonto-Festucenion; Des: Deschampsion caespitosae; Epa: Epilobietalia; Epn: Epilobion angustifolii; EPn: Erico-Pinion; F: Fagetalia sylvaticae; FB: Festuco-Bromea; FBt: Festuco-Brometea; FiC: Filipendulo-Cirsion oleracei; FPe: Festuco-Puccinellietea; FPi: Festuco-Puccinellietalia; Fru: Festucion rupicolae; Fvg: Festucion vaginatae; Fvl: Festucetalia valesiacae; GA: Galio-Alliarion; I: Indifferens; ined.: ineditum (kiadatlan közlés); Mag: Magnocaricion; Moa: Molinietalia coeruleae; MoA: Molinio-Arrhenatherea; Moa: Molinio- 
Juncetea; NA: Nardo-Agrostion tenuis; Ncn: Nanocyperion flavescentis; Onn: Onopordion acanthii; Phn: Phragmition; Pla: Plantaginetalia majoris; Pna: Populenion nigro-albae; PQ: Pino-Quercion; Prf: Prunion fruticosae; Pru: Prunetalia spinosae; Pte: Phragmitetea; Qc: Quercetalia cerridis; QFt: QuercoFagetea; Qpp: Quercetea pubescentis-petraeae; Qr: Quercetalia roboris; Qrp: Quercion robori-petraeae; S: summa (összeg); Sal: Salicion albae; SaS: Sambuco-Salicion capreae; SCn: Scheuchzerio-Caricetalia nigrae; Sea: Secalietea; Sel: Salicenion elaeagno-daphnoidis; Sio: Sisymbrion officinalis; Spu: Salicetalia purpureae; Str: Salicion triandrae; TA: Tilio platyphyllae-Acerenion pseudoplatani; Ulm: Ulmenion; VP: Vaccinio-Piceetea.

\section{Irodalom}

BeCKING R.W. (1957): The Zürich-Montpellier School of phytosociology. - The Botanical Review 23: 411488.

BoRHIDi A. (1993): A magyar flóra szociális magatartás típusai, természetességi és relatív ökológiai értékszámai. - Janus Pannonius Tudományegyetem, Pécs, 95 pp.

BoRHIDI A. (1995): Social behaviour types, the naturalness and relative ecological indicator values of the higher plants in the hungarian flora. - Acta Botanica Academiae Scientiarum Hungaricae 39: 97181.

Borhidi A. \& KEVEY B. (1996): An annotated checklist of the Hungarian plant communities II. - In: Borhidi A. (ed.): Critical revision of the Hungarian plant comuunities. Janus Pannonius University, Pécs, pp. 95-138.

Borhidi A., Kevey B. \& Lendvai G. (2012): Plant communities of Hungary. - Akadémiai Kiadó, Budapest, $544 \mathrm{pp}$.

Braun-Blanquet J. (1964): Pflanzensoziologie (ed. 3.). - Springer Verlag, Wien-New York, 865 pp.

HorvÁth F., Dobolyi Z. K., MORSCHHAUSER T., LŐKÖS L., KARAS L. \& SZERDAHELYI T. (1995): Flóra adatbázis 1.2. - Vácrátót, 267 pp.

JAKUCS P. (1967): Gedanken zur höheren Systematik der europäischen Laubwälder. - Contribuţii Botanice Cluj 1967: 159-166.

KEveY B. (2008): Magyarország erdőtársulásai (Forest associations of Hungary). Die Wälder von Ungarn - Tilia 14: 1-488. + CD-adatbázis (230 táblázat + 244 ábra).

Kevey B. (2016a): Puha- és keményfás ligeterdők kapcsolata a Szigetközben. - Botanikai Közlemények 103: 45-115.

KeveY B. (2016b): A fekete- és fehérnyáras ligeterdők kapcsolata a Szigetközben. - Botanikai Közlemények 103: 195-212 + Elektronikus mellékletek: E1-E4. táblázat.

KEVEY B. \& HiRMANN A. (2002): „NS” számítógépes cönológiai programcsomag - In: Aktuális flóra- és vegetációkutatások a Kárpát-medencében V. Pécs, 2002. március 8-10. (Összefoglalók), pp. 74.

KEvEY B. \& TóTH V. (2006): A Baranyai-Dráva-sík fehér nyárligetei (Senecioni sarracenici-Populetum albae KEVEY in BoRHIDI \& KeVEY 1996). - Natura Somogyiensis 9: 47-62.

Moor M. (1958): Die Pflanzengesellschaften schweizerischer Flußauen. - Mitteilungen der Schweizerischen Anstalt für das Forstliche Versuchswesen 34: 221-360, Zürich.

Mucina L., Grabherr G. \& Wallnöfer S. (1993): Die Pflanzengesellschaften Österreichs III. Wälder und Gebüsche. - Gustav Fischer, Jena - Stuttgart - New York, 353 pp.

Oberdorfer E. (1992): Süddeutsche Pflanzengesellschaften IV. A. Textband. - Gustav Fischer Verlag, Jena - Stuttgart - New York, $282 \mathrm{pp}$.

PoDANi J. (2001): SYN-TAX 2000 Computer Programs for Data Analysis in Ecologi and Systematics. Scientia, Budapest, 53 pp.

Soó R. (1930): Összehasonlító erdei vegetációtanulmányok az Alpokban, a Kárpátokban és a Magyar Középhegységben. - Erdészeti Kísérletek 32: 439-475, 559-566.

Soó R. (1964, 1966, 1968, 1970, 1973, 1980): A magyar flóra és vegetáció rendszertani-növényföldrajzi kézikönyve I-VI. - Akadémiai Kiadó, Budapest.

Beérkezett / received: 2020. 06. 29. • Elfogadva / accepted: 2020. 09. 14. 
Kitaibelia 25(2): 215-238.

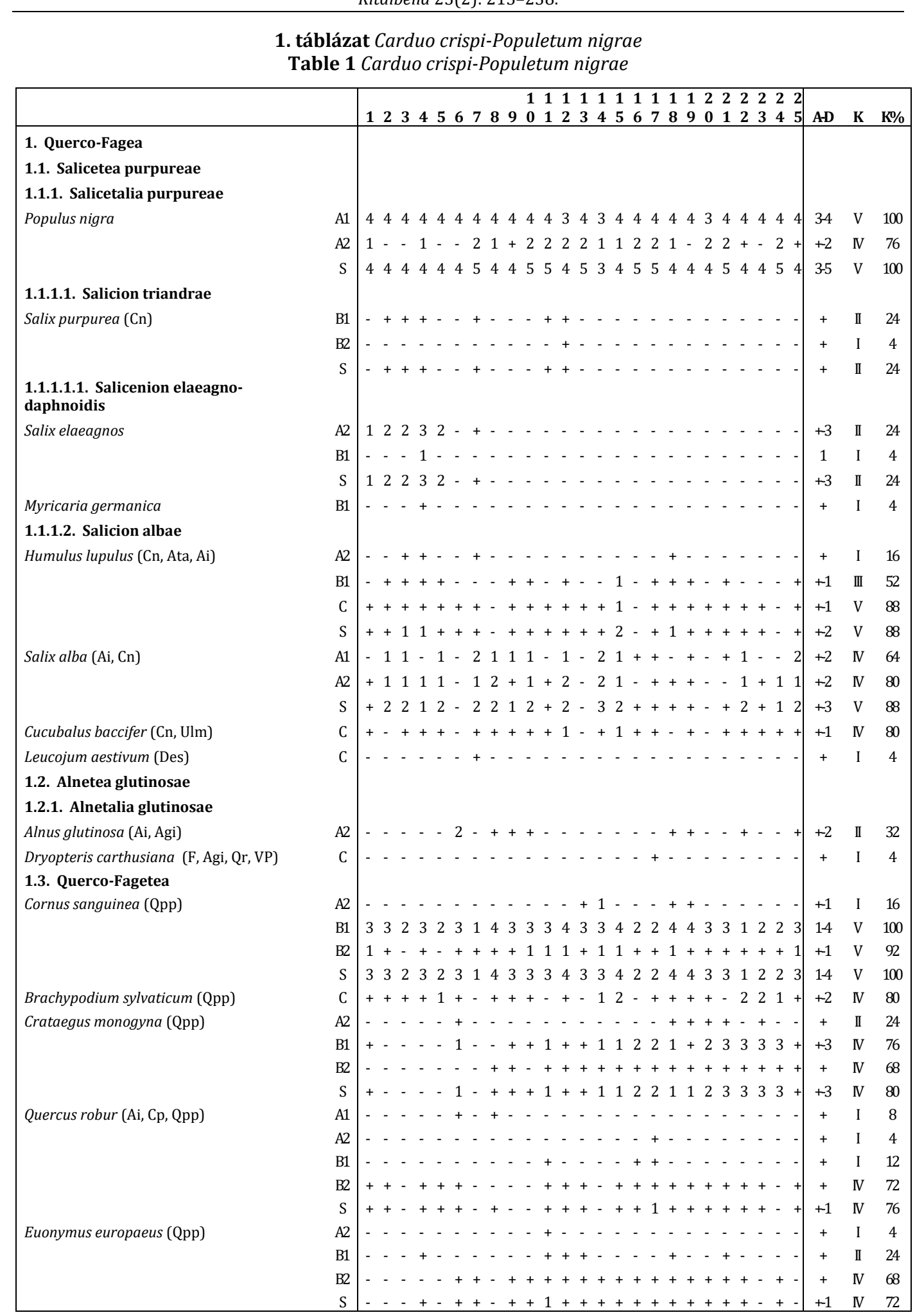


KEVEY \& CSETE (2020): Feketenyár-ligetek a Dráva mentén

\begin{tabular}{|c|c|c|c|c|c|c|c|c|c|c|c|c|c|c|c|c|c|c|c|c|c|c|c|c|c|c|c|}
\hline & & 12 & 3 & 4 & & & 7 & 8 & 9 & & & & & & & & & & & & & & & $\begin{array}{l}2 \\
5 \\
\end{array}$ & A-D & $\mathbf{K}$ & $\mathbf{K} \%$ \\
\hline \multirow[t]{3}{*}{ Ligustrum vulgare (Cp, Qpp) } & B1 & +- & + & + & + & 2 & - & - - & - & - & ++ & +- & & ++ & ++ & + & - & - & 2 & + & - & + & & - & +2 & III & 60 \\
\hline & B2 & +- & + & - & - & + & - & - & - & -+ & ++ & +- & + & ++ & ++ & ++ & + & - & + & + & - & + & & - & + & III & 56 \\
\hline & $S$ & +- & + & + & + & 2 & - & - - & - & -+ & ++ & +- & -+ & ++ & ++ & ++ & + & - & 2 & + & - & + & + & - & +2 & IV & 64 \\
\hline Fallopia dumetorum (Qpp, GA) & $\mathrm{C}$ & -+ & + & + & - & - & - & - - & - & +- & - - & -+ & ++ & +1 & $1+$ & +- & + & + & - & + & + & + & & + & +1 & III & 60 \\
\hline Geum urbanum (Epa, Cp, Qpp) & $\mathrm{C}$ & - & - & - & - & + & - & ++ & + & +- & - - & -- & - & ++ & ++ & ++ & + & - & - & + & + & + & & + & + & III & 56 \\
\hline \multirow[t]{4}{*}{ Clematis vitalba (Qpp) } & $\mathrm{A} 2$ & -- & - & - & - & - & - & - - & - & - - & - - & -+ & + & - - & - - & - - & - & - & - & - & - & + & 1 & - & +1 & I & 12 \\
\hline & B1 & - - & - & - & - & - & - & - - & - & - - & - & -+ & +- & + & +- & - - & - & - & - & + & - & + & & - & + & I & 20 \\
\hline & B2 & -+ & - & - & - & - & - & -+ & + & +- & -+ & ++ & ++ & ++ & ++ & +- & - & - & - & + & - & + & & + & + & III & 48 \\
\hline & $\mathrm{S}$ & -+ & - & - & - & - & - & -+ & + & +- & -+ & +1 & 1 & ++ & ++ & +- & - & - & - & + & - & 1 & & + & +1 & III & 48 \\
\hline Scrophularia nodosa (GA, Epa) & $\mathrm{C}$ & -+ & - & - & - & - & - & +- & - & - & -+ & ++ & + & ++ & +- & + & - & - & - & + & - & + & & + & + & III & 44 \\
\hline \multirow[t]{4}{*}{ Ulmus minor (Ai, Ulm, Qpp) } & A2 & - & - & - & - & + & - & ++ & + & - & - - & -- & - & - - & - - & - - & + & + & - & - & - & - & - & - & + & I & 20 \\
\hline & B1 & -- & - & - & - & + & - & + & + & + & $-\quad-$ & $-\quad-$ & - & - - & - - & - - & + & + & - & - & + & - & & - & + & II & 32 \\
\hline & B2 & - & - & - & - & + & - & + & + & + & - & -+ & + & - - & - - & - - & + & + & + & - & + & - & & - & + & II & 40 \\
\hline & $\mathrm{S}$ & - & - & - & - & 1 & - & 1 & 1 & + & - & -+ & + & - & - - & - - & 1 & 1 & + & - & + & - & & - & +1 & II & 40 \\
\hline \multirow[t]{4}{*}{ Acer campestre (Qpp) } & $\mathrm{A} 2$ & -- & - & - & - & - & - & - & + & - & - - & $-\quad-$ & - & - & - - & - - & - & - & - & - & - & - & - & - & + & I & 4 \\
\hline & B1 & -+ & - & - & + & - & - & - & + & - & - - & -- & - & - & - - & - - & - & - & - & - & - & - & - & - & + & I & 12 \\
\hline & B2 & ++ & - & - & + & - & - & - & + & - & - - & $-\quad-$ & - & - & + & +- & + & + & - & + & - & - & & - & + & II & 36 \\
\hline & $\mathrm{S}$ & ++ & - & - & + & - & - & - & 1 & - - & - - & - - & - & - - & + & +- & + & + & - & + & - & - & & - & +1 & II & 36 \\
\hline \multirow[t]{3}{*}{ Rhamnus catharticus (Qpp, Pru) } & B1 & - & - & + & - & - & - & - & - & - - & - - & - - & - & - & - - & + & - & - & - & - & - & - & & - & + & I & 12 \\
\hline & B2 & - & - & - & + & + & - & - & - & - & - - & - - & - & - & + & +- & - & - & + & + & - & + & - & - & + & II & 24 \\
\hline & $\mathrm{S}$ & - & - & + & + & + & - & - & - & - - & - - & -- & - & - - & + & ++ & + & - & + & + & - & + & & - & + & II & 36 \\
\hline Ranunculus ficaria & $\mathrm{C}$ & +2 & + & 1 & 1 & - & + & - & - & - - & - - & - - & - & -+ & ++ & +- & - & - & - & - & - & - & - & - & +2 & II & 32 \\
\hline Veronica sublobata & $\mathrm{C}$ & +1 & + & 1 & + & - & - & - & - & - & - - & $-\quad-$ & - & +- & - - & - - & - & - & - & + & - & - & - & + & +1 & II & 32 \\
\hline Viola suavis (Qpp) & $\mathrm{C}$ & - & - & - & - & - & - & + & + & - & - - & - & - & - & - - & - - & - & + & + & - & + & + & & - & +1 & II & 28 \\
\hline Dactylis polygama (Qpp, Cp) & $\mathrm{C}$ & -+ & - & - & - & - & - & + & + & -+ & ++ & +- & - & - & - - & - - & - & - & + & - & - & - & - & - & + & II & 24 \\
\hline Veronica chamaedrys (Qpp, Ara) & $\mathrm{C}$ & - & - & - & - & - & - & - & - & +- & - - & - - & - - & -+ & ++ & +- & - & - & + & - & - & - & - & + & + & I & 20 \\
\hline \multirow[t]{3}{*}{ Corylus avellana (Qpp) } & B1 & - & - & + & - & - & - & - & - & - & - - & - - & - & - & - - & - - & - & - & - & - & - & - & - & - & + & I & 4 \\
\hline & B2 & -+ & - & - & - & - & - & - & - & - & - - & $-\quad-$ & - & - - & - - & - - & - & - & - & - & - & - & & - & + & I & 8 \\
\hline & $\mathrm{S}$ & -+ & - & + & - & - & - & - & - & - & - - & - - & - & - & - - & - - & - & - & - & - & - & - & & - & + & I & 12 \\
\hline Galeopsis pubescens (Qpp, Epa) & $\mathrm{C}$ & - - & - & - & - & - & - & - & - & - - & - - & - & - & - & - - & - - & - & - & - & - & + & + & & - & + & I & 12 \\
\hline Ajuga reptans $(\mathrm{MoA})$ & $\mathrm{C}$ & -- & - & - & - & + & - & - & - & - & - - & $-\quad-$ & - & - & + & +- & - & - & - & - & - & - & - & - & + & I & 8 \\
\hline Carex divulsa & $\mathrm{C}$ & -- & - & - & - & - & - & - & - & - & - & $-\quad-$ & - & +- & - - & - - & - & - & - & - & - & - & - & + & + & I & 8 \\
\hline Cephalanthera longifolia & $\mathrm{C}$ & - & - & - & - & - & - & - & - & - & - & -- & - - & - & - - & - - & + & + & + & - & - & - & - & - & + & I & 8 \\
\hline Mycelis muralis & $\mathrm{C}$ & - & - & - & - & - & - & - & - & - & - & - - & - & -+ & +- & - - & + & + & - & - & - & - & - & - & + & I & 8 \\
\hline Poa nemoralis (Qpp) & $\mathrm{C}$ & - - & - & - & - & - & - & - & - & -+ & + & +- & - & - & - & - - & - & - & - & - & - & - & - & - & + & I & 8 \\
\hline Carex spicata (Qpp, Epa) & $\mathrm{C}$ & - & - & - & - & - & - & - & - & - & - & - & - & -+ & +- & - - & - & - & - & - & - & - & - & - & + & I & 4 \\
\hline Heracleum sphondylium (Qpp, MoA) & $\mathrm{C}$ & - & - & - & + & - & - & - & - & - & - & - & - & - & - & - - & - & - & - & - & - & - & - & - & + & I & 4 \\
\hline \multicolumn{28}{|l|}{ 1.3.1. Fagetalia sylvaticae } \\
\hline \multirow[t]{4}{*}{ Hedera helix } & A2 & 22 & 2 & 2 & 2 & 2 & + & - & - & - & -1 & 1 & - - & - & - & - - & - & 1 & + & + & - & 2 & & - & +2 & III & 52 \\
\hline & B1 & ++ & - & 1 & 1 & + & - & - & - & - & - & + & - & - & - & - - & + & + & + & + & + & + & & + & +1 & III & 56 \\
\hline & B2 & 43 & 3 & 2 & 3 & 4 & + & + & 2 & 2 & +3 & 3 & + & + & ++ & ++ & +1 & 12 & 4 & 4 & + & - 1 & & 1 & +4 & V & 100 \\
\hline & $S$ & 54 & 4 & 3 & 4 & 5 & + & + & 2 & 2 & +3 & 3 & + & + & ++ & ++ & +1 & 12 & 4 & 4 & + & 2 & & 1 & +5 & V & 100 \\
\hline Galeopsis speciosa (Epn, Ai) & $\mathrm{C}$ & - & + & - & + & - & - & + & + & + & + & + & ++ & ++ & +- & + & + & + & - & + & + & + & + & + & + & IV & 72 \\
\hline Aegopodium podagraria $(\mathrm{Ai}, \mathrm{Cp})$ & $\mathrm{C}$ & +2 & 2 & 1 & + & 1 & 1 & + & + & - & - & - & +2 & $2-$ & 1 & $1-$ & 3 & $3-$ & + & - & 2 & 1 & 2 & - & +3 & IV & 68 \\
\hline Circaea lutetiana (Ai) & $\mathrm{C}$ & - & - & - & - & 2 & + & 1 & 2 & 2 & + & - & + & ++ & ++ & ++ & +2 & 22 & $2-$ & + & - & + & 1 & 2 & +2 & IV & 68 \\
\hline Dryopteris filix-mas & $\mathrm{C}$ & - & - & - & - & + & - & + & + & - & - & - & - & -+ & ++ & ++ & + & - & + & - & - & - & + & + & + & II & 36 \\
\hline Moehringia trinervia & $\mathrm{C}$ & - - & - & - & - & - & - & - & + & + & - & - & - & ++ & +- & - - & - & - & - & - & - & + & + & + & + & II & 28 \\
\hline \multirow[t]{4}{*}{ Cerasus avium (Cp) } & A2 & - & + & - & - & - & - & - & - & - & - & - & - & - & - - & - - & - & - & - & - & - & - & - & - & + & I & 4 \\
\hline & B1 & - & + & - & - & - & - & - & - & - & - & - & - & - & - - & - - & - - & - & - & - & - & - & - & - & + & I & 4 \\
\hline & B2 & + & - & - & - & + & - & - & - & - & - & - & + & + & - - & - - & - & - & - & + & - & - & - & - & + & I & 20 \\
\hline & $\mathrm{S}$ & + & + & - & - & + & - & - & - & - & - & - & + & + & - & - - & - & - & - & + & - & - & - & - & + & II & 24 \\
\hline
\end{tabular}


Kitaibelia 25(2): 215-238.

\begin{tabular}{|c|c|c|c|c|c|c|c|c|c|c|c|c|c|c|c|c|c|c|c|c|c|c|c|c|c|c|c|c|}
\hline & & 12 & 23 & & & 6 & 7 & 8 & 9 & $\begin{array}{l}\mathbf{1} \\
\mathbf{0}\end{array}$ & & & & & & & & & & & & & & & & $A=D$ & $\mathbf{K}$ & $\mathbf{K} \%$ \\
\hline Galanthus nivalis & $\mathrm{C}$ & ++ & + & + & + & - & - & - & - & - & - & - & - & + & - & - & - & - & - & - & - & - & - & - & & + & II & 24 \\
\hline \multirow[t]{4}{*}{ Carpinus betulus $(\mathrm{Cp})$} & $\mathrm{A} 2$ & - & - & - & - & + & - & - & - & - & - & - & - & - & - & - & - & - & - & - & - & - & - & + & & + & I & 8 \\
\hline & $\mathrm{B} 1$ & - - & - & - & - & - & - & - & - & - & - & - & - & - & - & + & - & - & - & - & - & - & - & - & & + & I & 4 \\
\hline & B2 & - & - & - & - & + & - & - & - & - & - & - & - & - & - & - & - & + & - & + & - & - & - & + & & + & I & 16 \\
\hline & $S$ & - & - & - & - & + & - & - & - & - & - & - & - & - & - & + & - & + & - & + & - & - & - & + & & + & I & 20 \\
\hline Cardamine impatiens & $\mathrm{C}$ & - & - & - & - & - & - & - & - & - & - & - & - & + & + & + & - & - & - & - & + & - & - & - & & + & I & 16 \\
\hline Carex sylvatica & $\mathrm{C}$ & -- & - & - & + & + & - & + & - & - & - & - & - & - & - & - & - & - & - & + & - & - & - & - & & + & I & 16 \\
\hline Paris quadrifolia (Ata, Ai) & $\mathrm{C}$ & - & - & - & - & + & - & + & + & - & - & - & - & - & - & - & - & + & - & - & - & - & - & - & & + & I & 16 \\
\hline Pulmonaria officinalis & $\mathrm{C}$ & -- & - & - & + & - & - & + & + & + & - & - & - & - & - & - & - & - & - & - & - & - & - & - & & + & I & 16 \\
\hline Arum maculatum & $\mathrm{C}$ & - & + & + & + & - & - & - & - & - & - & - & - & - & - & - & - & - & - & - & - & - & - & - & & + & I & 12 \\
\hline Corydalis cava & $\mathrm{C}$ & +- & + & - & + & - & - & - & - & - & - & - & - & - & - & - & - & - & - & - & - & - & - & - & & + & I & 12 \\
\hline Viola reichenbachiana & $\mathrm{C}$ & -- & - & - & - & + & - & - & - & - & - & - & - & - & - & - & - & - & - & + & - & - & + & - & & + & I & 12 \\
\hline Asarum europaeum & $\mathrm{C}$ & - & - & - & - & + & - & + & - & - & - & - & - & - & - & - & - & - & - & - & - & - & - & - & & + & I & 8 \\
\hline Galium odoratum & $\mathrm{C}$ & -- & - & - & - & - & - & - & - & - & - & - & + & - & - & - & - & - & - & - & - & - & - & + & & + & I & 8 \\
\hline Sanicula europaea & $\mathrm{C}$ & -- & - & - & - & + & - & - & - & + & - & - & - & - & - & - & - & - & - & - & - & - & - & - & & + & I & 8 \\
\hline Stachys sylvatica (Epa) & $\mathrm{C}$ & - & - & - & - & - & - & - & + & - & - & - & - & - & - & - & - & - & - & - & - & - & - & + & & + & I & 8 \\
\hline Acer pseudo-platanus (TA) & $\mathrm{A} 2$ & -- & - & - & - & + & - & - & - & - & - & - & - & - & - & - & - & - & - & - & - & - & - & - & & + & I & 4 \\
\hline Anemone ranunculoides & $\mathrm{C}$ & -- & - & + & - & - & - & - & - & - & - & - & - & - & - & - & - & - & - & - & - & - & - & - & & + & I & 4 \\
\hline Gagea lutea $(\mathrm{Ai}, \mathrm{Cp})$ & $\mathrm{C}$ & -+ & + & - & - & - & - & - & - & - & - & - & - & - & - & - & - & - & - & - & - & - & - & - & & + & I & 4 \\
\hline Mercurialis perennis & $\mathrm{C}$ & -- & - & - & + & - & - & - & - & - & - & - & - & - & - & - & - & - & - & - & - & - & - & - & & + & I & 4 \\
\hline $\begin{array}{l}\text { Omphalodes scorpioides (TA) } \\
\text { 1.3.1.1. Alnion incanae }\end{array}$ & $\mathrm{C}$ & -- & - & - & - & - & - & - & - & - & - & - & - & - & - & - & - & - & - & - & - & 1 & - & - & & 1 & I & 4 \\
\hline Equisetum hyemale (F) & $\mathrm{C}$ & $2+$ & + & + & - & 1 & 2 & + & + & - & 2 & - & 3 & + & + & 2 & 4 & 3 & 4 & 2 & 4 & - & + & - & $3+$ & +4 & IV & 80 \\
\hline \multirow[t]{5}{*}{ Ulmus laevis (Sal, Ulm) } & $\mathrm{A} 1$ & $-\quad-$ & - & - & - & - & - & 1 & 1 & 1 & - & - & - & - & - & - & - & 1 & + & - & - & 1 & - & + & & +1 & II & 28 \\
\hline & $\mathrm{A} 2$ & -+ & + & + & + & - & - & + & 1 & + & - & - & + & - & - & - & - & - & + & + & + & + & - & + & & +1 & III & 52 \\
\hline & B1 & ++ & + & + & - & - & - & + & - & - & - & - & - & - & - & - & - & + & - & - & - & - & - & - & & + & II & 28 \\
\hline & B2 & +- & - & - & - & + & + & + & + & + & - & - & - & - & + & - & - & + & + & - & + & - & + & + & + & + & III & 52 \\
\hline & $S$ & ++ & + & + & + & + & + & 1 & 2 & 1 & - & - & + & - & + & - & - & 1 & 1 & + & + & 1 & + & 1 & $1+$ & +2 & N & 80 \\
\hline Dipsacus pilosus (GA) & $\mathrm{C}$ & - & - & - & - & - & - & 1 & + & + & - & - & - & + & + & + & + & + & + & - & - & + & + & + & ++ & +1 & III & 52 \\
\hline Festuca gigantea (Cn, Epa) & $\mathrm{C}$ & ++ & + & - & + & - & - & - & - & - & - & - & - & - & + & + & + & - & + & - & - & + & 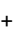 & + & & + & III & 48 \\
\hline \multirow{3}{*}{ Viburnum opulus (Ata) } & $\mathrm{B} 1$ & -- & - & + & - & - & - & + & - & - & - & - & - & - & - & - & - & - & - & + & + & - & - & - & & + & I & 16 \\
\hline & B2 & +- & - & + & - & + & - & - & - & - & + & + & + & - & - & - & + & - & + & + & - & - & - & + & & + & II & 40 \\
\hline & $S$ & +- & - & + & - & + & - & + & - & - & + & + & + & - & - & - & + & - & + & + & + & - & - & + & & + & III & 48 \\
\hline Carex brizoides (Ata) & $\mathrm{C}$ & +- & - & - & - & - & - & - & - & - & - & + & + & - & - & + & + & - & + & - & - & - & - & - & & + & II & 24 \\
\hline \multirow[t]{5}{*}{ Fraxinus angustifolia ssp. danubialis (Ata) } & A1 & - & - & - & - & - & - & - & + & - & - & - & - & - & - & - & - & - & - & - & - & - & - & - & & + & I & 4 \\
\hline & $\mathrm{A} 2$ & -- & - & - & - & - & - & - & + & - & - & - & - & - & - & - & - & - & + & - & - & - & - & - & & + & I & 8 \\
\hline & $\mathrm{B} 1$ & - & - & + & - & - & - & - & - & - & - & - & - & - & - & - & - & - & + & - & - & - & - & - & & + & I & 8 \\
\hline & B2 & -+ & - & + & - & + & - & - & + & - & - & - & - & - & - & - & - & - & + & - & - & - & - & - & & + & I & 20 \\
\hline & $S$ & -+ & + & + & - & + & - & - & 1 & - & - & - & - & - & - & - & - & - & 1 & - & - & - & - & - & & +1 & I & 20 \\
\hline Oenanthe banatica & $\mathrm{C}$ & +- & - & + & + & + & - & - & - & + & - & - & - & - & - & - & - & - & - & - & - & - & - & - & & + & I & 20 \\
\hline \multirow[t]{5}{*}{ Populus alba (Sal, AQ) } & $\mathrm{A} 1$ & -- & - & - & - & - & - & - & - & - & - & - & - & - & - & - & - & + & - & 1 & - & - & - & - & & +1 & I & 8 \\
\hline & $\mathrm{A} 2$ & -- & - & - & - & - & - & - & - & - & - & - & - & - & - & - & - & + & 1 & + & - & - & & - & & +2 & I & 16 \\
\hline & $\mathrm{B} 1$ & - & - & - & - & - & - & - & - & - & - & - & - & - & + & - & - & - & - & - & - & - & - & - & & + & I & 4 \\
\hline & B2 & - & - & - & - & - & - & - & - & - & - & - & - & - & - & - & - & - & + & + & - & - & - & - & & + & I & 8 \\
\hline & S & - & - & - & - & - & - & - & - & - & - & - & - & - & + & - & - & + & 1 & 1 & & - & 2 & - & & +2 & I & 20 \\
\hline Frangula alnus (Ata, Qr, PQ) & B2 & -- & - & - & - & + & - & - & - & - & + & - & - & - & - & - & - & + & - & - & - & - & - & - & & + & I & 12 \\
\hline \multirow[t]{3}{*}{ Padus avium } & $\mathrm{B} 1$ & -+ & - & - & + & - & - & - & - & - & - & - & - & - & - & - & - & - & - & - & - & - & - & - & & + & I & 8 \\
\hline & B2 & -- & - & - & + & - & - & - & - & - & - & - & - & - & - & - & - & - & - & - & - & - & - & - & + & + & I & 8 \\
\hline & S & -+ & + & - & + & - & - & - & - & - & - & - & - & - & - & - & - & - & - & - & - & - & - & - & & + & I & 12 \\
\hline Malus sylvestris (Qpp) & $\mathrm{A} 2$ & -- & - & - & - & - & - & - & - & - & - & - & - & - & + & - & - & - & - & + & - & - & - & - & & + & I & 8 \\
\hline Rumex sanguineus (Epa, Pna) & $\mathrm{C}$ & -- & - & - & - & - & - & + & - & + & - & - & - & - & - & - & - & - & - & - & - & - & - & - & & + & I & 8 \\
\hline Carex remota & $\mathrm{C}$ & $-\quad-$ & - & - & - & - & - & - & - & - & - & - & + & - & - & - & - & - & - & - & - & - & - & - & & + & I & 4 \\
\hline
\end{tabular}


KEVEY \& CSETE (2020): Feketenyár-ligetek a Dráva mentén

\begin{tabular}{|c|c|c|c|c|c|c|c|c|c|c|c|c|c|c|c|c|c|c|c|c|c|c|c|c|c|c|c|}
\hline & & & & & & 6 & & 8 & 9 & & 1 & 2 & 3 & 4 & & & & & & & & & & $\begin{array}{ll}2 & 2 \\
4 & 5\end{array}$ & A-D & $\mathbf{K}$ & K\% \\
\hline \multicolumn{28}{|l|}{ 1.3.1.2. Aremonio-Fagion } \\
\hline \multicolumn{27}{|l|}{ 1.4. Quercetea pubescentis-petraeae } & 44 \\
\hline \multirow[t]{3}{*}{ Prunus spinosa (Pru, Prf) } & $\mathrm{B} 1$ & - & $-\quad-$ & - & - & - & - & - & - & - & - & - & - & - & - & - & + & - & - & - & - & - & - & $-\quad-$ & + & I & 4 \\
\hline & B2 & - & & - & - & - & - & - & - & - & + & + & - & - & + & - & - & - & - & - & - & + & - & ++ & + & II & 24 \\
\hline & $\mathrm{S}$ & - & - - & - & & - & - & - & - & - & + & + & - & - & + & - & + & - & - & - & - & + & - & ++ & + & II & 28 \\
\hline Physalis alkekengi (Ulm) & $\mathrm{C}$ & - & - - & - & - & - & - & - & - & - & - & - & - & - & - & - & - & + & + & - & + & - & + & +- & + & I & 20 \\
\hline \multirow{4}{*}{ Pyrus pyraster $(\mathrm{Cp})$} & $\mathrm{A} 2$ & - & $-\quad-$ & - & - & - & - & - & - & - & - & - & - & - & - & - & + & - & - & - & - & - & - & $-\quad-$ & + & I & 4 \\
\hline & B1 & - & $-\quad-$ & - & - & - & - & - & - & - & - & - & - & - & + & + & + & - & - & - & - & - & - & $-\quad-$ & + & I & 12 \\
\hline & B2 & - & $-\quad-$ & - & - & - & - & - & - & - & - & - & - & - & - & - & - & - & - & + & - & - & - & $-\quad-$ & + & I & 4 \\
\hline & $S$ & - & $-\quad-$ & - & - & - & - & - & - & - & - & - & - & - & + & + & + & - & - & + & - & - & - & $-\quad-$ & + & I & 16 \\
\hline Rosa canina agg. (Pru, Prf) & B2 & - & - - & - & - & - & - & - & - & - & - & + & - & - & - & + & - & - & - & - & - & - & - & - & + & I & 8 \\
\hline Astragalus glycyphyllos & $\mathrm{C}$ & - & - - & - & - & - & - & - & - & - & - & - & - & - & - & - & - & - & - & - & - & - & + & -- & + & I & 4 \\
\hline Lithospermum officinale & $\mathrm{C}$ & - & $-\quad-$ & - & - & - & - & - & - & - & - & - & - & - & - & - & - & - & - & + & - & - & - & - & + & I & 4 \\
\hline Quercus cerris (Qr, PQ) & B2 & - & $-\quad-$ & - & - & - & - & - & - & - & - & + & - & - & - & - & - & - & - & - & - & - & - & - & + & I & 4 \\
\hline \multicolumn{28}{|l|}{ 2. Cypero-Phragmitea } \\
\hline \multicolumn{28}{|l|}{ 2.1. Phragmitetea } \\
\hline Iris pseudacorus (Sal, Ata, Ai) & $\mathrm{C}$ & -+ & ++ & - & + & + & + & - & + & + & + & + & + & - & - & + & + & - & - & + & + & - & - & - & + & III & 56 \\
\hline Phalaris arundinacea (Des) & $\mathrm{C}$ & -+ & ++ & + & + & - & 1 & - & - & - & + & + & - & - & + & + & - & - & + & - & + & - & - & -- & +1 & III & 44 \\
\hline Carex riparia (Mag, Cgr, Moa, Sal, Ata) & $\mathrm{C}$ & +- & - - & - & - & - & - & - & - & - & - & - & + & - & - & + & + & + & - & - & + & - & + & -+ & + & II & 32 \\
\hline Solanum dulcamara (Cn, Bia, Spu) & $\mathrm{C}$ & - & - - & - & - & - & + & + & + & + & - & - & + & - & - & - & - & + & + & - & + & - & - & $-\quad-$ & + & II & 32 \\
\hline Phragmites australis (Moa, FPe, Spu, Ata) & $\mathrm{C}$ & -+ & +- & - & - & - & + & - - & - & - & - & - & - & + & + & - & - & - & + & + & - & - & - & +- & + & II & 28 \\
\hline Poa palustris (Moa, Des, Spu, Ata, Ai) & $\mathrm{C}$ & - & - - & - & - & - & - & - & - & - & - & - & + & - & + & + & - & - & + & - & - & - & - & +- & + & I & 20 \\
\hline Stachys palustris (Moa, Cn, Bon, Spu, Ata) & $\mathrm{C}$ & - & - - & - & - & + & + & - & - & - & - & - & - & - & - & - & - & - & + & - & - & + & - & $-\quad-$ & + & I & 16 \\
\hline Glyceria maxima $(\mathrm{Phn}, \mathrm{Spu})$ & $\mathrm{C}$ & - & - - & - & + & - & - & - & - & - & - & - & - & - & - & - & - & - & - & - & - & - & - & - & + & I & 4 \\
\hline Hypericum tetrapterum (FiC) & $\mathrm{C}$ & - & - - & - & - & + & - & - & - & - & - & - & - & - & - & - & - & - & - & - & - & - & - & $-\quad-$ & + & I & 4 \\
\hline Myosotis scorpioides (Moa, Spu, Ata, Cn) & $\mathrm{C}$ & - & - - & - & - & - & + & - & - & - & - & - & - & - & - & - & - & - & - & - & - & - & - & $-\quad-$ & + & I & 4 \\
\hline Scutellaria galericulata (Moa, Spu, Ata) & $\mathrm{C}$ & - & $-\quad-$ & - & - & - & + & - & - & - & - & - & - & - & - & - & - & - & - & - & - & - & - & $-\quad-$ & + & I & 4 \\
\hline \multicolumn{28}{|l|}{ 2.1.1. Magnocaricetalia } \\
\hline \multicolumn{28}{|l|}{ 2.1.1.1. Magnocaricion } \\
\hline 2.1.1.1.1. Caricenion gracilis & & & & & & & & & & & & & & & & & & & & & & & & & & & \\
\hline Carex acuta (Pte, Mag, Moa, Ata, Ai) & $\mathrm{C}$ & ++ & ++ & + & + & + & + & - & - & - & + & 1 & 1 & - & + & - & + & 1 & + & 1 & + & + & + & $1+$ & +1 & IV & 80 \\
\hline 3. Molinio-Arrhenatherea & & & & & & & & & & & & & & & & & & & & & & & & & & & \\
\hline Poa trivialis (Pte, Spu, Ata, Ai) & $\mathrm{C}$ & ++ & ++ & + & + & + & + & + & + & + & - & + & + & 2 & 1 & + & + & + & + & - & + & - & - & -1 & +2 & IV & 80 \\
\hline Poa pratensis (Qpp) & $\mathrm{C}$ & - & $-\quad-$ & - & - & - & - & - & - & - & - & - & + & - & - & - & + & - & - & - & - & - & - & - & + & I & 8 \\
\hline Achillea millefolium (Ara) & $\mathrm{C}$ & - & $-\quad-$ & - & - & - & - & - & - & - & + & - & - & - & - & - & - & - & - & - & - & - & - & $-\quad-$ & + & I & 4 \\
\hline Briza media (FBt, Qpp) & $\mathrm{C}$ & - & - - & - & - & - & - & - & - & - & + & - & - & - & - & - & - & - & - & - & - & - & - & $-\quad-$ & + & I & 4 \\
\hline Campanula patula (Arn) & $\mathrm{C}$ & - & $-\quad-$ & - & - & - & - & - & - & - & - & - & - & - & - & + & - & - & - & - & - & - & - & - & + & I & 4 \\
\hline Cardamine pratensis (Mag, Des, Sal, Ata, Ai) & $\mathrm{C}$ & - & - - & - & - & - & - & - & - & - & - & - & - & - & - & - & + & - & - & - & - & - & - & -- & + & I & 4 \\
\hline Festuca pratensis (Des) & $\mathrm{C}$ & - & - - & - & - & - & - & - & - & - & - & - & - & - & - & + & - & - & - & - & - & - & - & - & + & I & 4 \\
\hline Holcus lanatus (Qpp, Qrp, PQ) & $\mathrm{C}$ & - & - - & - & - & - & - & - & - & - & + & - & - & - & - & - & - & - & - & - & - & - & - & $-\quad-$ & + & I & 4 \\
\hline Rumex crispus (Mag, Cn, Bia, Pla, AR) & $\mathrm{C}$ & - & - - & - & - & - & - & - & - & - & - & - & - & - & - & - & - & - & - & + & - & - & - & - & + & I & 4 \\
\hline Vicia cracca (Mag, Sea, Aon, Qpp) & $\mathrm{C}$ & - & - - & - & - & - & - & - & - & - & - & - & - & - & - & - & + & - & - & - & - & - & - & $-\quad-$ & + & I & 4 \\
\hline 3.1. Molinio-Juncetea & & & & & & & & & & & & & & & & & & & & & & & & & & & \\
\hline Symphytum officinale (Pte, Cn, Spu, Ata, Ai) & $\mathrm{C}$ & ++ & ++ & - & + & + & + & + & + & + & + & + & + & + & + & + & + & 1 & + & + & 1 & - & + & +- & +1 & $\mathrm{~V}$ & 88 \\
\hline Deschampsia caespitosa (Des, Sal, Ata, Ai) & $\mathrm{C}$ & - & -+ & - & - & + & & - & - & - & - & - & - & - & - & - & - & - & - & - & - & - & - & - & + & I & 8 \\
\hline 3.1.1. Molinietalia coeruleae & & & & & & & & & & & & & & & & & & & & & & & & & & & \\
\hline Angelica sylvestris (Mag, Ata, Ai) & $\mathrm{C}$ & ++ & +- & + & + & + & + & + & + & + & + & + & + & + & + & + & + & + & - & + & + & - & - & -+ & + & IV & 80 \\
\hline Valeriana officinalis agg. (Mag, FiC, Qc, I) & $\mathrm{C}$ & - & - - & - & - & + & - & - & - & - & + & + & + & - & - & - & + & - & - & + & - & - & - & $-\quad-$ & + & II & 24 \\
\hline Ophioglossum vulgatum (NA, Arn) & $\mathrm{C}$ & - & - - & - & - & + & - & - & - & - & - & - & - & - & - & - & - & - & - & + & - & - & - & $-\quad-$ & + & I & 8 \\
\hline Orchis militaris (FBt, Qpp) & $\mathrm{C}$ & - & - - & - & - & - & - & - & - & - & - & - & - & - & - & - & - & - & - & + & - & - & - & $-\quad-$ & + & I & 4 \\
\hline 3.2. Arrhenatheretea & & & & & & & & & & & & & & & & & & & & & & & & & & & \\
\hline 3.2.1. Arrhenatheretalia & & & & & & & & & & & & & & & & & & & & & & & & & & & \\
\hline Anthriscus sylvestris (Arc, GA, Spu, Ai) & $\mathrm{C}$ & ++ & ++ & + & & - & - & - & - & - & - & - & - & - & - & - & - & - & - & - & - & - & - & $-\quad-$ & + & I & 20 \\
\hline Arrhenatherum elatius (Alo, Arn, Fvl, Qpp) & $\mathrm{C}$ & - & $-\quad-$ & - & - & - & - & - & - & - & + & - & + & - & - & + & - & - & - & - & - & - & - & - & + & $\mathrm{I}$ & 12 \\
\hline
\end{tabular}


Kitaibelia 25(2): 215-238.

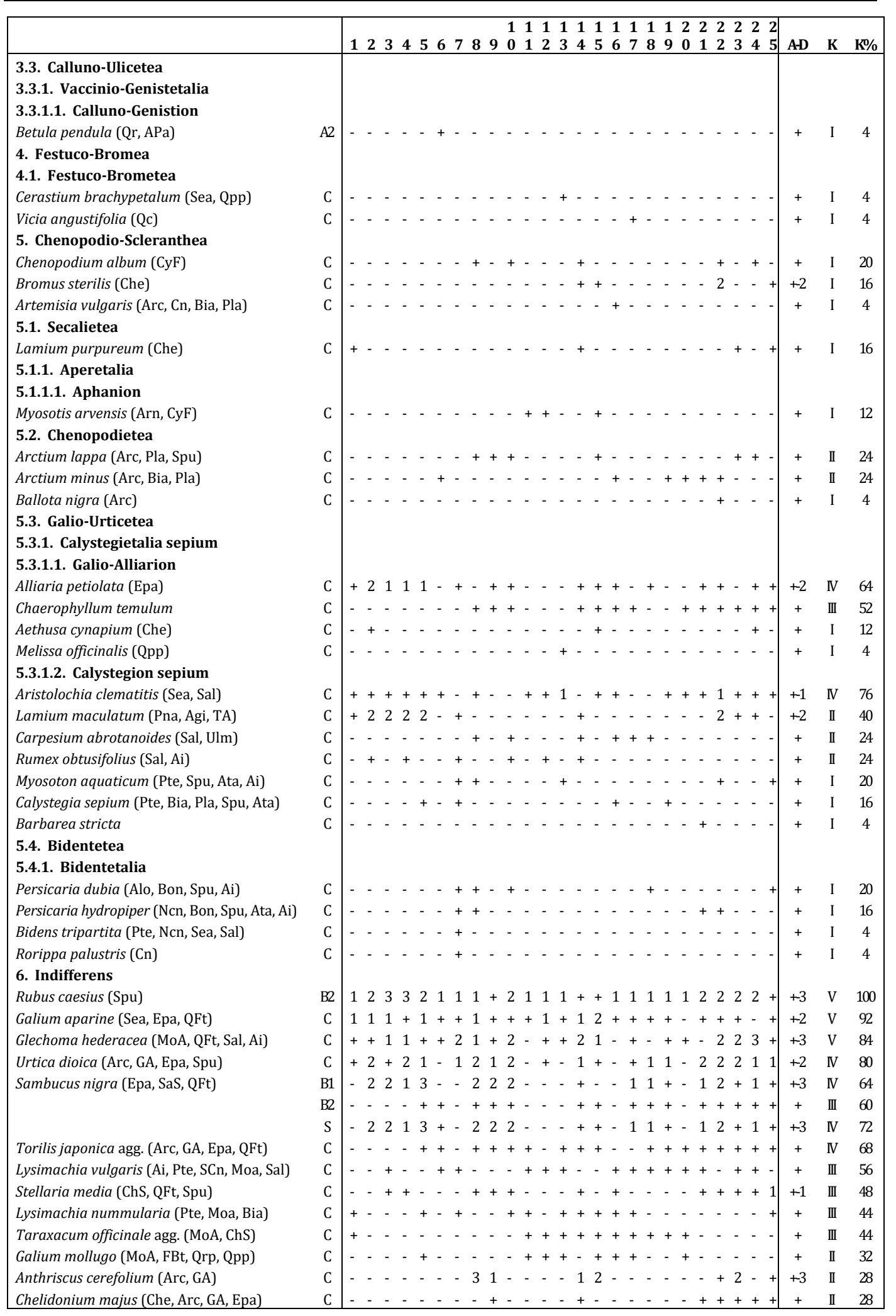


KEVEY \& CSETE (2020): Feketenyár-ligetek a Dráva mentén

\begin{tabular}{|c|c|c|c|c|c|c|c|c|c|c|c|c|c|c|c|c|c|c|c|c|c|c|c|c|c|c|c|}
\hline & & & & & & & 7 & 8 & 9 & $\begin{array}{l}\mathbf{1} \\
\mathbf{0}\end{array}$ & 1 & $\begin{array}{l}1 \\
2 \\
\end{array}$ & $\begin{array}{l}1 \\
3 \\
\end{array}$ & & & & & & & & & & & $\begin{array}{ll}22 \\
45 \\
\end{array}$ & A-D & $\mathbf{K}$ & $\mathbf{K} \%$ \\
\hline Ranunculus repens (Pte, MoA, ChS, Spu, Ata) & $\mathrm{C}$ & ++ & + & 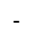 & - & 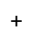 & $T_{T}$ & - & - & + & $T$ & - & - & + & - & - & - & - & - & - & - & - & - - & - & + & II & 28 \\
\hline Calamagrostis epigeios (Moa, Fvg, Epa) & $\mathrm{C}$ & - & - & - & - & - & - & - & - & - & + & + & - & - & - & + & + & + & - & - & - & - & -+ & +- & + & II & 24 \\
\hline Vicia hirsuta (MoA, FB, Sea, Qpp) & $\mathrm{C}$ & - & - & - & - & - & - & - & - & - & + & + & - & - & - & + & + & - & - & - & + & - & & - & + & I & 20 \\
\hline Agrostis stolonifera (Pte, Moa, FPe, Bia, Pla) & $\mathrm{C}$ & - & - & - & - & - & - & + & - & - & - & + & - & - & + & - & - & - & - & - & - & - & & - & + & I & 12 \\
\hline Dactylis glomerata (MoA, FB, Che, Pla, Qpp) & $\mathrm{C}$ & - & - & - & - & - & - & - & - & - & - & - & + & - & + & + & - & - & - & - & - & - & - - & - & + & I & 12 \\
\hline Equisetum arvense (MoA, Sea, Sal, Ata, Ai) & $\mathrm{C}$ & - & - & - & - & - & + & - & - & - & - & - & + & - & - & - & - & - & - & - & - & - & & -+ & + & I & 12 \\
\hline Carex flacca (Mag, Moa, Arn, FBt, Qpp) & $\mathrm{C}$ & - & - & - & - & - & - & - & - & - & - & - & - & - & - & + & + & - & - & - & - & - & - - & - & + & I & 8 \\
\hline Carex hirta (Pte, MoA, Pla) & $\mathrm{C}$ & - & - & + & - & - & - & - & - & - & - & - & - & - & - & - & + & - & - & - & - & - & & - & + & I & 8 \\
\hline Mentha aquatica (Pte, Moa, Spu, Ata, Ai) & $\mathrm{C}$ & - & - & - & - & + & + & - & - & - & - & - & - & - & - & - & - & - & - & - & - & - & - - & - & + & I & 8 \\
\hline Trifolium pratense (Mag, MoA, CyF, Sea, Pla) & $\mathrm{C}$ & - & - & - & - & - & - & - & - & - & + & - & - & - & - & + & - & - & - & - & - & - & - - & - & + & I & 8 \\
\hline Allium scorodoprasum (Qpp, Sea, Che) & $\mathrm{C}$ & - & - & - & - & - & - & - & - & - & - & - & - & - & - & + & - & - & - & - & - & - & & -- & + & I & 4 \\
\hline Cruciata laevipes (Arn, Fru, Arc, Cia, Qpp) & $\mathrm{C}$ & - & - & - & - & - & - & - & - & - & - & + & - & - & - & - & - & - & - & - & - & - & - - & - & + & I & 4 \\
\hline Elymus repens (MoA, $\mathrm{FPi}, \mathrm{FB}, \mathrm{ChS}, \mathrm{Pla})$ & $\mathrm{C}$ & -- & - & - & - & - & - & - & - & - & - & - & + & - & - & - & - & - & - & - & - & - & - - & -- & + & I & 4 \\
\hline Euphorbia cyparissias (FB, ChS, Epa, Qpp) & $\mathrm{C}$ & - & - & - & - & - & - & - & - & - & - & - & - & - & - & - & + & - & - & - & - & - & & - & + & I & 4 \\
\hline Galium verum (Moa, FB, Qpp) & $\mathrm{C}$ & - & - & - & - & - & - & - & - & - & - & - & - & - & - & - & + & - & - & - & - & - & & - & + & I & 4 \\
\hline Juniperus communis (NA, Fvg, Qpp, EPn) & B1 & - & - & - & - & - & - & - & - & - & - & - & - & - & - & - & - & - & - & + & - & - & & - & + & I & 4 \\
\hline Leucanthemum vulgare (MoA, Ara) & $\mathrm{C}$ & - & - & - & - & - & - & - & - & - & + & - & - & - & - & - & - & - & - & - & - & - & - - & - & + & I & 4 \\
\hline Medicago lupulina (MoA, FPe, AlS, FBt, ChS) & $\mathrm{C}$ & - & - & - & - & - & - & - & - & - & - & - & + & - & - & - & - & - & - & - & - & - & & - - & + & I & 4 \\
\hline Oenothera biennis (ChS, Sio, Onn, Spu) & $\mathrm{C}$ & - & - & + & - & - & - & - & - & - & - & - & - & - & - & - & - & - & - & - & - & - & & - & + & I & 4 \\
\hline Plantago major (Pla) & $\mathrm{C}$ & - & - & - & - & - & - & - & - & + & - & - & - & - & - & - & - & - & - & - & - & - & & - & + & I & 4 \\
\hline Potentilla reptans (Mag, MoA, FPi, Bia, Pla) & $\mathrm{C}$ & - & - & - & - & + & - & - & - & - & - & - & - & - & - & - & - & - & - & - & - & - & - - & - - & + & I & 4 \\
\hline Rorippa sylvestris (Ncn, Des, ChS, AR, Spu) & $\mathrm{C}$ & - & - & - & - & - & - & - & - & - & - & - & + & - & - & - & - & - & - & - & - & - & & - & + & I & 4 \\
\hline Rubus fruticosus agg. (QFt, Epa, SaS) & B2 & - & - & - & - & - & - & - & - & - & - & - & - & - & - & - & - & - & - & - & - & - & +- & - & + & I & 4 \\
\hline Torilis japonica (Arc, GA, Epa, QFt) & $\mathrm{C}$ & -- & - & - & - & - & - & - & - & - & - & + & - & - & - & - & - & - & - & - & - & - & & - - & + & I & 4 \\
\hline \multicolumn{28}{|l|}{ 7. Adventiva } \\
\hline Solidago gigantea & $\mathrm{C}$ & 11 & 12 & 1 & 1 & + & 2 & + & + & - & 2 & 1 & 2 & - & + & 1 & 1 & + & + & + & + & - & & ++ & +3 & $\mathrm{~V}$ & 88 \\
\hline \multirow[t]{4}{*}{ Morus alba } & $\mathrm{A} 2$ & - & - & - & + & - & - & + & - & - & - & - & - & 1 & - & - & - & + & + & - & + & - & - - & -+ & +1 & II & 28 \\
\hline & B1 & - & - & + & - & - & - & + & - & - & - & - & - & - & - & - & - & - & - & + & - & - & - - & - - & + & I & 12 \\
\hline & B2 & - & - & - & - & + & - & - & + & + & - & - & - & - & - & - & - & + & + & - & + & + & - & +- & + & II & 32 \\
\hline & $\mathrm{S}$ & - & - & + & + & + & - & + & + & + & - & - & - & 1 & - & - & - & + & + & + & + & + & - & ++ & +1 & III & 56 \\
\hline Erigeron annuus & $\mathrm{C}$ & - & - & - & - & - & - & + & + & + & + & + & + & + & + & + & - & + & - & + & - & - & & -+ & + & III & 52 \\
\hline Impatiens glandulifera & $\mathrm{C}$ & -+ & + & + & + & - & + & + & + & - & - & - & - & + & - & + & - & + & + & - & - & - & - & - & + & III & 44 \\
\hline \multirow[t]{4}{*}{ Acer negundo } & $\mathrm{A} 2$ & -+ & + & + & + & - & 1 & - & - & - & - & + & - & - & - & - & - & 1 & - & - & - & - & - & -1 & +1 & II & 32 \\
\hline & B1 & - & 1 & 1 & + & - & 2 & - & - & - & - & - & - & - & - & - & - & + & - & - & - & - & - & $-\quad-$ & +2 & I & 20 \\
\hline & B2 & -+ & + & - & + & - & + & - & + & + & - & + & - & - & - & - & - & + & - & - & - & - & - & - - & + & II & 32 \\
\hline & S & -+ & +1 & 1 & 1 & - & 2 & - & + & + & - & + & - & - & - & - & - & 1 & - & - & - & - & - & -1 & +2 & II & 40 \\
\hline \multirow[t]{4}{*}{ Fraxinus pennsylvanica } & $\mathrm{A} 2$ & +- & - & - & - & - & - & - & - & - & - & - & - & - & - & - & - & - & - & - & - & - & - & - & + & I & 4 \\
\hline & $\mathrm{B} 1$ & -1 & 1 & + & - & - & - & - & - & - & - & - & - & - & - & - & - & - & - & - & - & - & - & - & +1 & I & 12 \\
\hline & B2 & -+ & + & + & - & - & + & + & - & - & - & - & - & - & - & + & - & - & + & - & - & - & - & ++ & + & II & 36 \\
\hline & S & +1 & 1 & + & - & - & + & + & - & - & - & - & - & - & - & + & - & - & + & - & - & - & - & ++ & +1 & II & 40 \\
\hline Aster $\times$ salignus & $\mathrm{C}$ & -+ & + & + & + & - & 2 & - & - & 1 & - & - & - & - & - & - & - & + & + & - & + & - & - & - & +2 & II & 36 \\
\hline \multirow[t]{3}{*}{ Amorpha fruticosa } & $\mathrm{B} 1$ & $2-$ & + & + & - & - & 1 & - & - & - & - & + & - & - & + & + & - & - & - & + & - & - & - & - - & +2 & II & 32 \\
\hline & B2 & - & - & + & - & - & + & - & - & - & - & - & - & - & - & - & - & - & - & + & - & - & - & - & + & I & 12 \\
\hline & $\mathrm{S}$ & $2-$ & + & + & - & - & 1 & - & - & - & - & + & - & - & + & + & - & - & - & + & - & - & & - & +2 & II & 32 \\
\hline \multirow[t]{4}{*}{ Vitis vulpina } & $\mathrm{A} 2$ & 12 & 21 & 1 & - & - & - & - & - & - & - & - & - & - & - & - & - & - & - & - & - & - & - & -2 & $1-2$ & I & 20 \\
\hline & B1 & -+ & + & + & + & - & - & - & - & - & - & - & - & - & - & - & - & - & - & - & - & - & - & -+ & + & I & 20 \\
\hline & B2 & - & - & - & + & - & - & - & - & - & - & - & - & - & - & - & - & + & - & - & + & - & - & -+ & + & I & 16 \\
\hline & $\mathrm{S}$ & 12 & 21 & 1 & + & - & - & - & - & - & - & - & - & - & - & - & - & + & - & - & + & - & - & -2 & +2 & II & 32 \\
\hline Impatiens parviflora & $\mathrm{C}$ & - & - & - & - & - & - & + & 3 & - & - & - & - & - & - & + & - & - & - & - & - & + & & +- & +3 & II & 24 \\
\hline Robinia pseudo-acacia & $\mathrm{A} 2$ & -+ & + & + & - & - & - & - & - & - & + & - & - & - & - & - & - & - & - & 1 & - & - & - & - & +1 & I & 16 \\
\hline & B1 & - & - & - & - & - & - & - & - & - & + & - & - & - & - & - & - & - & - & - & + & - & - & - & + & I & 8 \\
\hline & B2 & - & - & - & - & - & - & + & - & - & + & - & - & - & - & - & - & - & - & + & - & - & - & - & + & I & 12 \\
\hline & S & -+ & + & + & - & - & - & + & - & - & 1 & - & - & - & - & - & - & - & - & 1 & + & - & - & - & +1 & II & 24 \\
\hline Conyza canadensis & $\mathrm{C}$ & - & - & - & - & - & - & - & - & - & - & - & - & + & - & - & - & + & - & & - & + & & +- & + & I & 20 \\
\hline Juglans regia & $\mathrm{B} 1$ & - & - & + & + & - & - & - & - & - & - & - & - & - & - & - & - & - & + & & - & - & - & $-\quad-$ & + & I & 12 \\
\hline & B2 & - & - & + & + & & - & - & - & - & - & - & - & - & - & - & - & + & + & & - & - & - & - & + & I & 16 \\
\hline & $\mathrm{S}$ & - - & - & + & + & - & - & - & - & - & - & - & - & - & - & - & - & + & & & - & & - & - & + & I & 16 \\
\hline
\end{tabular}


Kitaibelia 25(2): 215-238.

\begin{tabular}{|c|c|c|c|c|c|c|c|c|c|c|c|c|c|c|c|c|c|c|c|c|c|c|c|c|c|c|c|}
\hline & & 12 & & & 5 & 6 & 7 & 8 & 9 & & $\begin{array}{l}1 \\
1\end{array}$ & & $\begin{array}{l}1 \\
3\end{array}$ & $\begin{array}{l}1 \\
4\end{array}$ & $\begin{array}{l}1 \\
5\end{array}$ & $\begin{array}{l}1 \\
6\end{array}$ & & $\begin{array}{l}1 \\
8\end{array}$ & $\begin{array}{l}1 \\
9\end{array}$ & $\begin{array}{l}2 \\
0\end{array}$ & & & & & $A$ & $\mathbf{K}$ & K\% \\
\hline \multirow[t]{3}{*}{ Parthenocissus inserta } & $\mathrm{A} 2$ & - - & 1 & - & - & - & - & - & - & - & - & - & - & - & - & - & - & - & - & - & - & - & - & - - & 1 & I & 4 \\
\hline & B2 & - & 1 & - & - & - & - & - & + & - & - & - & - & - & - & - & - & - & - & - & + & - & - & -+ & + & I & 16 \\
\hline & $\mathrm{S}$ & - & 2 & - & - & - & - & - & + & - & - & - & - & - & - & - & - & - & - & - & + & - & - & -+ & + & I & 16 \\
\hline Phytolacca americana & $\mathrm{C}$ & - - & - & - & - & - & - & - & - & - & - & - & - & - & - & - & - & - & - & - & + & 1 & + & +- & + & I & 16 \\
\hline Echinocystis lobata & $\mathrm{C}$ & - & - & - & - & - & - & - & - & - & - & - & - & + & - & - & - & - & - & - & + & - & - & -+ & + & I & 12 \\
\hline Oxalis stricta & $\mathrm{C}$ & - - & - & - & - & - & - & - & - & - & - & - & - & - & + & - & - & - & - & - & - & - & - & -+ & + & I & 8 \\
\hline Rudbeckia laciniata & $\mathrm{C}$ & -+ & - & - & - & - & + & - & - & - & - & - & - & - & - & - & - & - & - & - & - & - & - & - - & + & I & 8 \\
\hline \multirow[t]{3}{*}{ Ailanthus altissima } & B1 & - - & - & - & - & - & - & - & + & - & - & - & - & - & - & - & - & - & - & - & - & - & - & - - & + & I & 4 \\
\hline & B2 & -- & - & - & - & - & - & - & + & - & - & - & - & - & - & - & - & - & - & - & - & - & - & - & + & I & 4 \\
\hline & $\mathrm{S}$ & $-\quad-$ & - & - & - & - & - & - & + & - & - & - & - & - & - & - & - & - & - & - & - & - & - & - & + & I & 4 \\
\hline Celtis occidentalis & B1 & - - & - & - & - & - & - & - & - & - & - & - & - & - & - & - & - & - & - & + & - & - & - & - & + & I & 4 \\
\hline Pinus sylvestris & $\mathrm{A} 2$ & - & - & - & - & - & - & - & - & - & - & - & - & - & - & - & - & - & - & - & - & - & 1 & - & 1 & I & 4 \\
\hline
\end{tabular}

2. táblázat Felvételi adatok I.

Table 2 Data of relevés I.

\begin{tabular}{|l|c|c|c|c|c|c|c|c|c|c|c|c|c|}
\hline \multicolumn{1}{|c|}{$\mathbf{2 / 1}$} & $\mathbf{1}$ & $\mathbf{2}$ & $\mathbf{3}$ & $\mathbf{4}$ & $\mathbf{5}$ & $\mathbf{6}$ & $\mathbf{7}$ & $\mathbf{8}$ & $\mathbf{9}$ & $\mathbf{1 0}$ & $\mathbf{1 1}$ & $\mathbf{1 2}$ & $\mathbf{1 3}$ \\
\hline Kvadrát felvételi sorszáma & 17196 & 17197 & 17198 & 17199 & 17200 & 17213 & 17211 & 17206 & 17207 & 17208 & 14253 & 14255 & 14256 \\
Felvételi évszám 1. & 2012 & 2011 & 2011 & 2011 & 2011 & 2018 & 2018 & 2018 & 2018 & 2018 & 2007 & 2007 & 2007 \\
Felvételi időpont 1. & 0329 & 04.01 & 04.01 & 04.01 & 09.16 & 09.06 & 09.06 & 09.06 & 09.06 & 09.06 & 05.24 & 0524 & 05.24 \\
Felvételi évszám 2. & 2015 & 2011 & 2011 & 2011 & 2012 & 2019 & 2019 & 2019 & 2019 & 2019 & 2012 & 2012 & 2012 \\
Felvételi időpont 2. & 09.18 & 09.16 & 09.16 & 09.16 & 03.29 & 05.23 & 05.23 & 05.23 & 05.23 & 05.23 & 04.07 & 04.07 & 04.07 \\
Tengerszint feletti magasság & 130 & 131 & 130 & 130 & 131 & 112 & 108 & 110 & 110 & 110 & 108 & 107 & 108 \\
Lejtőszög (fok) & 0 & 0 & 0 & 0 & 0 & 0 & 0 & 0 & 0 & 0 & 0 & 0 & 0 \\
Felső lombkoronaszint borítása (\%) & 60 & 70 & 65 & 60 & 70 & 70 & 75 & 70 & 65 & 60 & 60 & 50 & 60 \\
Felső lombkoronaszint magassága (m) & 20 & 23 & 23 & 22 & 25 & 25 & 22 & 25 & 28 & 22 & 22 & 20 & 25 \\
Átlagos törzsátmérő (cm) & 40 & 45 & 45 & 45 & 55 & 55 & 40 & 60 & 60 & 45 & 40 & 35 & 50 \\
Alsó lombkoronaszint borítása (\%) & 30 & 40 & 40 & 50 & 40 & 20 & 25 & 20 & 5 & 20 & 15 & 25 & 10 \\
Alsó lombkoronaszint magassága (m) & 15 & 17 & 15 & 15 & 18 & 18 & 17 & 18 & 18 & 15 & 15 & 13 & 17 \\
Cserjeszint borítása (\%) & 60 & 60 & 50 & 50 & 50 & 60 & 20 & 70 & 60 & 60 & 50 & 75 & 50 \\
Cserjeszint magassága (m) & 2,5 & 3 & 25 & 2,5 & 3 & 3 & 2 & 3,5 & 3,5 & 4 & 3 & 3 & 4 \\
Újulat borítása (\%) & 80 & 50 & 60 & 60 & 60 & 70 & 5 & 5 & 25 & 30 & 10 & 40 & 5 \\
Gyepszint borítása (\%) & 20 & 70 & 60 & 50 & 40 & 25 & 80 & 80 & 80 & 60 & 50 & 10 & 80 \\
Felvételi terület nagysága (m²) & 1600 & 1600 & 1600 & 1600 & 1600 & 1200 & 1600 & 1600 & 1600 & 1600 & 1600 & 1600 & 1600 \\
\hline
\end{tabular}

\begin{tabular}{|l|c|c|c|c|c|c|c|c|c|c|c|c|}
\hline \multicolumn{1}{|c|}{$\mathbf{2 / 2}$} & $\mathbf{1 4}$ & $\mathbf{1 5}$ & $\mathbf{1 6}$ & $\mathbf{1 7}$ & $\mathbf{1 8}$ & $\mathbf{1 9}$ & $\mathbf{2 0}$ & $\mathbf{2 1}$ & $\mathbf{2 2}$ & $\mathbf{2 3}$ & $\mathbf{2 4}$ & $\mathbf{2 5}$ \\
\hline Kvadrát felvételi sorszáma & 17201 & 17202 & 17203 & 17204 & 17209 & 17210 & 17212 & 17190 & 17191 & 17193 & 17195 & 17205 \\
Felvételi évszám 1. & 2008 & 2008 & 2008 & 2008 & 2018 & 2018 & 2018 & 2019 & 2018 & 2018 & 2018 & 2014 \\
Felvételi időpont 1. & 06.03 & 06.03 & 06.03 & 06.03 & 09.10 & 09.17 & 09.10 & 06.04 & 09.17 & 09.10 & 09.10 & 05.01 \\
Felvételi évszám 2. & 2015 & 2015 & 2015 & 2015 & 2019 & 2019 & 2019 & 2020 & 2019 & 2019 & 2019 & 2015 \\
Felvételi időpont 2. & 05.01 & 05.01 & 05.01 & 05.01 & 05.20 & 05.20 & 05.20 & 05.13 & 05.20 & 05.20 & 05.20 & 09.17 \\
Tengerszint feletti magasság & 107 & 106 & 106 & 107 & 107 & 107 & 104 & 103 & 103 & 104 & 104 & 96 \\
Lejtőszög (fok) & 0 & 0 & 0 & 0 & 0 & 0 & 0 & 0 & 0 & 0 & 0 & 0 \\
Felső lombkoronaszint borítása (\%) & 60 & 65 & 60 & 70 & 70 & 60 & 50 & 70 & 60 & 60 & 65 & 70 \\
Felső lombkoronaszint magassága (m) & 23 & 20 & 22 & 25 & 27 & 26 & 27 & 28 & 25 & 28 & 27 & 23 \\
Átlagos törzsátmérő (cm) & 60 & 45 & 40 & 40 & 60 & 70 & 60 & 50 & 60 & 65 & 60 & 40 \\
Alsó lombkoronaszint borítása (\%) & 25 & 10 & 15 & 10 & 10 & 10 & 25 & 20 & 5 & 25 & 30 & 20 \\
Alsó lombkoronaszint magassága (m) & 16 & 10 & 15 & 16 & 18 & 18 & 15 & 20 & 18 & 20 & 20 & 15 \\
Cserjeszint borítása (\%) & 50 & 60 & 40 & 50 & 70 & 70 & 75 & 60 & 60 & 70 & 70 & 35 \\
Cserjeszint magassága (m) & 3,5 & 3,5 & 3 & 3,5 & 3 & 3,5 & 3 & 3,5 & 4 & 3 & 3 & 3 \\
Újulat borítása (\%) & 3 & 5 & 5 & 5 & 10 & 25 & 70 & 40 & 25 & 25 & 20 & 3 \\
Gyepszint borítása (\%) & 80 & 70 & 85 & 80 & 50 & 60 & 50 & 85 & 80 & 70 & 70 & 60 \\
Felvételi terület nagysága (m²) & 1600 & 1600 & 1600 & 1600 & 1600 & 1600 & 1600 & 1600 & 1200 & 1600 & 1600 & 1200 \\
\hline
\end{tabular}


KEVEY \& CSETE (2020): Feketenyár-ligetek a Dráva mentén

3. táblázat Felvételi adatok II.

Table 3 Data of relevés II.

\begin{tabular}{|c|c|c|c|c|}
\hline Sorszám & Település & Dülő & Koordináták & Szerző \\
\hline 1 & Zákány & Sziget & ÉSz 46 16' 34.77" / KH 16 53' 52.59" & Kevey ined. \\
\hline 2 & Zákány & Sziget & ÉSz 46 $16^{\prime} 38.15^{\prime \prime} /$ KH $16^{\circ} 53^{\prime} 56.07^{\prime \prime}$ & Kevey ined. \\
\hline 3 & Zákány & Sziget & ÉSz 46 16' 36.39" / KH $16^{\circ} 53^{\prime} 24.85^{\prime \prime}$ & Kevey ined. \\
\hline 4 & Zákány & Sziget & ÉSz 46 16' 35.94" / KH 16 53' 35.94" & Kevey ined. \\
\hline 5 & Zákány & Sziget & ÉSz 46 16' 39.46" / KH 16 54' 08.74" & Kevey ined. \\
\hline 6 & Vízvár & Felső-Lóka & ÉSz 46 06' 27.92" / KH $17^{\circ} 13^{\prime} 05.51^{\prime \prime}$ & Kevey ined. \\
\hline 7 & Vízvár & Alsó-Lóka & ÉSz 46 04' 58.17" / KH $17^{\circ} 13^{\prime} 36.86^{\prime \prime}$ & Kevey ined. \\
\hline 8 & Heresznye & Rasztina & ÉSz 46 $02^{\prime} 11.65^{\prime \prime} / \mathrm{KH} 17^{\circ} 15^{\prime} 37.01^{\prime \prime}$ & Kevey ined. \\
\hline 9 & Heresznye & Rasztina & ÉSz 46 $02^{\prime} 28.10^{\prime \prime}$ / KH $17^{\circ} 15^{\prime} 31.81^{\prime \prime}$ & Kevey ined. \\
\hline 10 & Heresznye & Rasztina & ÉSz 46º $02^{\prime} 27.95^{\prime \prime}$ / KH $17^{\circ} 15^{\prime} 36.42^{\prime \prime}$ & Kevey ined. \\
\hline 11 & Babócsa & Jelkus & ÉSz 455 59' 25.71" / KH $17^{\circ} 17^{\prime} 45.91^{\prime \prime}$ & Kevey - Csete - Lendvai ined. \\
\hline 12 & Babócsa & Jelkus & ÉSz 45 59' 26.93" / KH $17^{\circ} 17^{\prime} 51.44^{\prime \prime}$ & Kevey - Csete - Lendvai ined. \\
\hline 13 & Babócsa & Jelkus & ÉSz 45 59' $23.65^{\prime \prime}$ / KH $17^{\circ} 17^{\prime} 44.33^{\prime \prime}$ & Kevey - Csete - Lendvai ined. \\
\hline 14 & Djuretina & Jelkus & ÉSz 455 59' 48.74" / KH $17^{\circ} 16^{\prime} 56.12^{\prime \prime}$ & Kevey - Csete ined. \\
\hline 15 & Djuretina & Jelkus & ÉSz 455 59' 45.74" / KH $17^{\circ} 17^{\prime} 03.02^{\prime \prime}$ & Kevey - Csete ined. \\
\hline 16 & Djuretina & Jelkus & ÉSz 455 59' 44.32"' / KH $17^{\circ} 17^{\prime} 07.00^{\prime \prime}$ & Kevey - Csete ined. \\
\hline 17 & Djuretina & Jelkus & ÉSz 455 59' 44.54"' / KH $17^{\circ} 17^{\prime} 10.91^{\prime \prime}$ & Kevey - Csete ined. \\
\hline 18 & Barcs & Jamina & ÉSz 45 $57^{\prime} 34.63^{\prime \prime}$ / KH $17^{\circ} 20^{\prime} 53.39^{\prime \prime}$ & Kevey ined. \\
\hline 19 & Barcs & Jamina & ÉSz 45 $57^{\prime} 26.37^{\prime \prime}$ / KH $17^{\circ} 20^{\prime} 36.84^{\prime \prime}$ & Kevey ined. \\
\hline 20 & Barcs & Verbina & ÉSz 45 $56^{\prime} 36.40^{\prime \prime}$ / KH $17^{\circ} 29^{\prime} 35.87^{\prime \prime}$ & Kevey ined. \\
\hline 21 & Drávatamási & Szigecske & ÉSz 455 56' 27.41" / KH $17^{\circ} 30^{\prime} 23.64^{\prime \prime}$ & Kevey ined. \\
\hline 22 & Drávatamási & Szigecske & ÉSz 455 $56^{\prime} 07.06^{\prime \prime} / \mathrm{KH} 17^{\circ} 31^{\prime} 50.72^{\prime \prime}$ & Kevey ined. \\
\hline 23 & Drávatamási & Szigecske & ÉSz 455 56' 13.55" / KH $17^{\circ} 31^{\prime} 40.64^{\prime \prime}$ & Kevey ined. \\
\hline 24 & Drávatamási & Szigecske & ÉSz 45 56' 14.38" / KH $17^{\circ} 31^{\prime} 22.96^{\prime \prime}$ & Kevey ined. \\
\hline 25 & Drávapalkonya & Szerb-sziget & ÉSz 45 46' 41.43"' / KH $18^{\circ} 10^{\prime} 27.39^{\prime \prime}$ & Kevey ined. \\
\hline
\end{tabular}

4. táblázat Karakterfajok aránya I.

Table 4 Proportion of diagnostic species I.

P.nigrae Dráva: Carduo crispi-Populetum nigrae, Dráva-ártér (Kevey et al. ined.: 25 felv.)

P.albae Dráva: Senecioni sarracenici-Populetum albae, Dráva-ártér (KEVEY \& TóTH 2006: 20 felv.)

P.nigrae Szigetköz: Carduo crispi-Populetum nigrae, Szigetköz (Kevey 2008: 25 felv.)

P.albae Szigetköz: Senecioni sarracenici-Populetum albae, Szigetköz (KEvEY 2008: 25 felv.)

\begin{tabular}{|l|cc|cc|cc|c|c|}
\hline & \multicolumn{3}{|c|}{ C s o p o r t r é s z e s e d é s } & \multicolumn{3}{c|}{ C s o p o r t t o m e $\mathbf{~}$. } \\
\cline { 2 - 8 } & Pn Dráva & Pa Dráva & Pn Szk Pa Szk & Pn Dráva & Pa Dráva & Pn Szk & Pa Szk \\
\hline Querco-Fagea & 0,00 & 0,00 & 0,00 & 0,00 & 0,00 & 0,00 & 0,00 & 0,00 \\
Salicetea purpureae & 0,00 & 0,00 & 0,00 & 0,00 & 0,00 & 0,00 & 0,00 & 0,00 \\
Salicetalia purpureae & 4,39 & 3,23 & 6,81 & 3,95 & 29,14 & 4,45 & 25,60 & 1,89 \\
Salicion triandrae & 0,22 & 0,00 & 0,20 & 0,00 & 0,02 & 0,00 & 0,02 & 0,00 \\
Salicenion elaeagno-daphnoidis & 0,52 & 0,00 & 0,00 & 0,08 & 1,35 & 0,00 & 0,00 & 0,01 \\
Salicion triandrae s.l. & 0,74 & 0,00 & 0,20 & 0,08 & 1,37 & 0,00 & 0,02 & 0,01 \\
Salicion albae & 3,55 & 3,87 & 5,70 & 6,42 & 2,14 & 10,62 & 6,42 & 12,84 \\
Populenion nigro-albae & 0,24 & 0,29 & 0,85 & 1,14 & 0,31 & 0,03 & 0,66 & 0,61 \\
Salicion albae s.l. & 3,79 & 4,16 & 6,55 & 7,56 & 2,45 & 10,65 & 7,08 & 13,45 \\
Salicetalia purpureae s.l. & 8,92 & 7,39 & 13,56 & 11,59 & 32,96 & 15,10 & 32,70 & 15,35 \\
Salicetea purpureae s.l. & 8,92 & 7,39 & 13,56 & 11,59 & 32,96 & 15,10 & 32,70 & 15,35 \\
Alnetea glutinosae & 0,00 & 0,00 & 0,00 & 0,00 & 0,00 & 0,00 & 0,00 & 0,00 \\
Alnetalia glutinosae & 2,71 & 3,14 & 2,89 & 1,86 & 0,55 & 1,03 & 0,52 & 0,40 \\
Alnion glutinosae & 0,01 & 0,02 & 0,02 & 0,00 & 0.00 & 0.00 & 0.00 & 0.00 \\
Alnetalia glutinosae s.l. & 2,72 & 3,16 & 2,91 & 1,86 & 0,55 & 1,03 & 0,52 & 0,40 \\
Alnetea glutinosae s.l. & 2,72 & 3,16 & 2,91 & 1,86 & 0,55 & 1,03 & 0,52 & 0,40 \\
\hline
\end{tabular}


Kitaibelia 25(2): 215-238.

\begin{tabular}{|c|c|c|c|c|c|c|c|c|}
\hline & \multicolumn{4}{|c|}{ C s o p or tr é szes e d é $s$} & \multicolumn{4}{|c|}{ 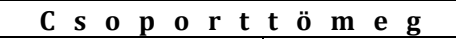 } \\
\hline & Pn Dráva & Pa Dráva & Pn Szk & Pa Szk & Pn Dráva & Pa Dráva & Pn Szk & PaSzk \\
\hline Querco-Fagetea & 9,85 & 13,26 & 4,51 & 9,76 & 11,43 & 18,16 & 3,59 & 21,35 \\
\hline Fagetalia sylvaticae & 8,63 & 11,21 & 0,54 & 5,32 & 15,88 & 5,91 & 0,22 & 1,61 \\
\hline Alnion incanae & 8,16 & 9,66 & 6,17 & 10,33 & 6,66 & 13,63 & 6,19 & 14,51 \\
\hline Alnenion glutinosae-incanae & 0,40 & 0,27 & 0,42 & 0,85 & 0,40 & 0,29 & 0,52 & 0,97 \\
\hline Ulmenion & 1,52 & 2,34 & 0,73 & 0,93 & 0,40 & 0,83 & 0,35 & 0,21 \\
\hline Alnion incanae s.l. & 10,08 & 12,27 & 7,32 & 12,11 & 7,46 & 14,75 & 7,06 & 15,69 \\
\hline Fagion sylvaticae & 0,00 & 0,00 & 0,00 & 0,00 & 0,00 & 0,00 & 0,00 & 0,00 \\
\hline Eu-Fagenion & 0,00 & 0,04 & 0,00 & 0,00 & 0.00 & 0.00 & 0.00 & 0.00 \\
\hline Carpinenion betuli & 2,17 & 1,64 & 0,33 & 2,17 & 1,02 & 0,73 & 0,19 & 1,05 \\
\hline Tilio-Acerenion & 0,26 & 0,24 & 0,54 & 0,63 & 0,33 & 0,04 & 0,53 & 0,56 \\
\hline Fagion sylvaticae s.l. & 2,43 & 1,92 & 0,87 & 2,80 & 1,35 & 0,77 & 0,72 & 1,61 \\
\hline Aremonio-Fagion & 0,82 & 0,40 & 0,00 & 0,00 & 0,97 & 0,06 & 0,00 & 0,00 \\
\hline Fagetalia sylvaticae s.l. & 21,96 & 25,80 & 8,73 & 20,23 & 25,66 & 21,49 & 8,00 & 18,91 \\
\hline Quercetalia roboris & 0,12 & 0,09 & 0,00 & 0,00 & 0,01 & 0,01 & 0,00 & 0,00 \\
\hline Quercion robori-petraeae & 0,14 & 0,00 & 0,02 & 0,05 & 0,01 & 0,00 & 0,00 & 0,00 \\
\hline Quercetalia roboris s.l. & 0,26 & 0,09 & 0,02 & 0,05 & 0,02 & 0,01 & 0,00 & 0,00 \\
\hline Querco-Fagetea s.l. & 32,07 & 39,15 & 13,26 & 30,04 & 37,11 & 39,66 & 11,59 & 40,26 \\
\hline Quercetea pubescentis-petraeae & 7,60 & 8,07 & 2,39 & 6,48 & 9,77 & 10,41 & 1,89 & 9,09 \\
\hline Orno-Cotinetalia & 0,00 & 0,00 & 0,00 & 0,00 & 0,00 & 0,00 & 0,00 & 0,00 \\
\hline Orno-Cotinion & 0,00 & 0,09 & 0,00 & 0,00 & 0,00 & 0,01 & 0,00 & 0,00 \\
\hline Orno-Cotinetalia s.l. & 0,00 & 0,09 & 0,00 & 0,00 & 0,00 & 0,01 & 0,00 & 0,00 \\
\hline Quercetalia cerridis & 0,13 & 0,00 & 0,00 & 0,00 & 0,01 & 0,00 & 0,00 & 0,00 \\
\hline Aceri tatarici-Quercion & 0,12 & 0,73 & 0,13 & 0,65 & 0,11 & 7,93 & 0,11 & 9,49 \\
\hline Quercetalia cerridis s.l. & 0,25 & 0,73 & 0,13 & 0,65 & 0,12 & 7,93 & 0,11 & 9,49 \\
\hline Prunetalia spinosae & 0,45 & 0,03 & 0,03 & 0,03 & 0,05 & 0,00 & 0,00 & 0,00 \\
\hline Prunion fruticosae & 0,22 & 0,00 & 0,03 & 0,03 & 0,02 & 0,00 & 0,00 & 0,00 \\
\hline Prunetalia spinosae s.l. & 0,67 & 0,03 & 0,06 & 0,06 & 0,07 & 0,00 & 0,00 & 0,00 \\
\hline Quercetea pubescentis-petraeae s.l. & 8,52 & 8,92 & 2,58 & 7,19 & 9,96 & 18,35 & 2,00 & 18,58 \\
\hline Querco-Fagea s.l. & 52,23 & 58,62 & 32,31 & 50,68 & 80,58 & 74,14 & 46,81 & 74,59 \\
\hline Abieti-Piceea & 0,02 & 0,00 & 0,00 & 0,00 & 0,00 & 0,00 & 0,00 & 0,00 \\
\hline Vaccinio-Piceetea & 0,00 & 0,07 & 0,00 & 0,00 & 0,00 & 0,01 & 0,00 & 0,00 \\
\hline Pino-Quercetalia & 0,00 & 0,00 & 0,00 & 0,00 & 0,00 & 0,00 & 0,00 & 0,00 \\
\hline Pino-Quercion & 0,10 & 0,04 & 0,00 & 0,00 & 0,01 & 0,00 & 0,00 & 0,00 \\
\hline Pino-Quercetalia s.l. & 0,10 & 0,04 & 0,00 & 0,00 & 0,01 & 0,00 & 0,00 & 0,00 \\
\hline Vaccinio-Piceetea s.l. & 0,10 & 0,11 & 0,00 & 0,00 & 0,01 & 0,01 & 0,00 & 0,00 \\
\hline Abieti-Piceea s.l. & 0,12 & 0,11 & 0,00 & 0,00 & 0,01 & 0,01 & 0,00 & 0,00 \\
\hline Lemno-Potamea & 0,00 & 0,00 & 0,00 & 0,00 & 0.00 & 0.00 & 0.00 & 0.00 \\
\hline Potametea & 0,00 & 0,00 & 0,02 & 0,00 & 0.00 & 0.00 & 0.00 & 0.00 \\
\hline Lemno-Potamea s.l. & 0,00 & 0,00 & 0,02 & 0,00 & 0.00 & 0.00 & 0.00 & 0.00 \\
\hline Cypero-Phragmitea & 0,00 & 0,00 & 0,00 & 0,00 & 0,00 & 0,00 & 0,00 & 0,00 \\
\hline Phragmitetea & 2,76 & 2,31 & 6,56 & 3,66 & 0,42 & 0,26 & 2,66 & 0,66 \\
\hline Phragmitetalia & 0,00 & 0,00 & 0,00 & 0,00 & 0.00 & 0.00 & 0.00 & 0.00 \\
\hline Phragmition & 0,02 & 0,00 & 0,00 & 0,00 & 0.00 & 0.00 & 0.00 & 0.00 \\
\hline Phragmitetalia s.l. & 0,02 & 0,00 & 0,00 & 0,00 & 0.00 & 0.00 & 0.00 & 0.00 \\
\hline Nasturtio-Glycerietalia & 0,00 & 0,00 & 0,00 & 0,00 & 0,00 & 0,00 & 0,00 & 0,00 \\
\hline Glycerio-Sparganion & 0,00 & 0,00 & 0,49 & 0,21 & 0,00 & 0,00 & 0,05 & 0,02 \\
\hline Nasturtio-Glycerietalia s.l. & 0,00 & 0,00 & 0,49 & 0,21 & 0,00 & 0,00 & 0,05 & 0,02 \\
\hline Magnocaricetalia & 0,00 & 0,00 & 0,00 & 0,00 & 0,00 & 0,00 & 0,00 & 0,00 \\
\hline Magnocaricion & 0,91 & 0,62 & 1,02 & 0,57 & 0,13 & 0,07 & 0,10 & 0,07 \\
\hline Caricenion gracilis & 0,35 & 0,18 & 0,23 & 0,04 & 0,07 & 0,02 & 0,02 & 0,00 \\
\hline Magnocaricion s.l. & 1,26 & 0,80 & 1,25 & 0,61 & 0,20 & 0,09 & 0,12 & 0,07 \\
\hline Magnocaricetalia s.l. & 1,26 & 0,80 & 1,25 & 0,61 & 0,20 & 0,09 & 0,12 & 0,07 \\
\hline Phragmitetea s.l. & 4,04 & 3,11 & 8,30 & 4,48 & 0,62 & 0,35 & 2,83 & 0,75 \\
\hline
\end{tabular}


KEVEY \& CSETE (2020): Feketenyár-ligetek a Dráva mentén

\begin{tabular}{|c|c|c|c|c|c|c|c|c|}
\hline & \multicolumn{4}{|c|}{ Csoportrészesedés } & \multicolumn{4}{|c|}{ 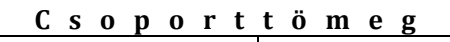 } \\
\hline & Pn Dráva & Pa Dráva & Pn Szk & Pa Szk & Pn Dráva & Pa Dráva & Pn Szk & Pa Szk \\
\hline Isoëto-Nanojuncetea & 0,00 & 0,00 & 0,00 & 0,00 & 0,00 & 0,00 & 0,00 & 0,00 \\
\hline Nanocyperetalia & 0,00 & 0,00 & 0,00 & 0,00 & 0,00 & 0,00 & 0,00 & 0,00 \\
\hline Nanocyperion flavescentis & 0,08 & 0,00 & 0,96 & 0,09 & 0,01 & 0,00 & 0,11 & 0,01 \\
\hline Nanocyperetalia s.l. & 0,08 & 0,00 & 0,96 & 0,09 & 0,01 & 0,00 & 0,11 & 0,01 \\
\hline Isoëto-Nanojuncetea s.l. & 0,08 & 0,00 & 0,96 & 0,09 & 0,01 & 0,00 & 0,11 & 0,01 \\
\hline Montio-Cardaminetea & 0,00 & 0,00 & 0,00 & 0,00 & 0.00 & 0.00 & 0.00 & 0.00 \\
\hline Montio-Cardaminetalia & 0,00 & 0,00 & 0,00 & 0,00 & 0.00 & 0.00 & 0.00 & 0.00 \\
\hline Cardamini-Montion & 0,00 & 0,00 & 0,03 & 0,00 & 0.00 & 0.00 & 0.00 & 0.00 \\
\hline Montio-Cardaminetalia s.l. & 0,00 & 0,00 & 0,03 & 0,00 & 0.00 & 0.00 & 0.00 & 0.00 \\
\hline Montio-Cardaminetea s.l. & 0,00 & 0,00 & 0,03 & 0,00 & 0.00 & 0.00 & 0.00 & 0.00 \\
\hline Cypero-Phragmitea s.l. & 4,12 & 3,11 & 9,29 & 4,57 & 0,63 & 0,35 & 2,94 & 0,76 \\
\hline Oxycocco-Caricea nigrae & 0,00 & 0,00 & 0,00 & 0,00 & 0,00 & 0,00 & 0,00 & 0,00 \\
\hline Scheuchzerio-Caricetea nigrae & 0,00 & 0,00 & 0,00 & 0,00 & 0,00 & 0,00 & 0,00 & 0,00 \\
\hline Scheuchzerio-Caricetalia nigrae & 0,17 & 0,03 & 0,08 & 0,01 & 0,02 & 0,00 & 0,01 & 0,00 \\
\hline Scheuchzerio-Caricetea nigrae s.l. & 0,17 & 0,03 & 0,08 & 0,01 & 0,02 & 0,00 & 0,01 & 0,00 \\
\hline Oxycocco-Caricea nigrae s.l. & 0,17 & 0,03 & 0,08 & 0,01 & 0,02 & 0,00 & 0,01 & 0,00 \\
\hline Molinio-Arrhenatherea & 1,74 & 1,36 & 1,88 & 1,20 & 0,62 & 0,99 & 0,84 & 0,74 \\
\hline Molinio-Juncetea & 1,23 & 0,94 & 2,37 & 1,20 & 0,17 & 0,11 & 0,41 & 0,14 \\
\hline Molinietalia coeruleae & 0,63 & 0,63 & 1,11 & 0,69 & 0,07 & 0,06 & 0,12 & 0,08 \\
\hline Deschampsion caespitosae & 0,60 & 0,30 & 1,68 & 1,22 & 0,08 & 0,03 & 1,83 & 0,26 \\
\hline Filipendulo-Cirsion oleracei & 0,13 & 0,03 & 0,21 & 0,09 & 0,01 & 0,00 & 0,02 & 0,01 \\
\hline Alopecurion pratensis & 0,12 & 0,05 & 0,31 & 0,19 & 0,01 & 0,01 & 0,10 & 0,02 \\
\hline Molinietalia coeruleae s.l. & 1,48 & 1,01 & 3,31 & 2,19 & 0,17 & 0,10 & 2,07 & 0,37 \\
\hline Molinio-Juncetea s.l. & 2,71 & 1,95 & 5,68 & 3,39 & 0,34 & 0,21 & 2,48 & 0,51 \\
\hline Arrhenatheretea & 0,00 & 0,00 & 0,00 & 0,00 & 0,00 & 0,00 & 0,00 & 0,00 \\
\hline Arrhenatheretalia & 0,31 & 0,24 & 0,08 & 0,24 & 0,03 & 0,02 & 0,01 & 0,02 \\
\hline Arrhenatherion elatioris & 0,24 & 0,01 & 0,05 & 0,00 & 0,03 & 0,00 & 0,00 & 0,00 \\
\hline Cynosurion cristati & 0,00 & 0,00 & 0,02 & 0,03 & 0.00 & 0.00 & 0.00 & 0.00 \\
\hline Arrhenatheretalia s.l. & 0,55 & 0,25 & 0,15 & 0,27 & 0,06 & 0,02 & 0,01 & 0,02 \\
\hline Arrhenatheretea s.l. & 0,55 & 0,25 & 0,15 & 0,27 & 0,06 & 0,02 & 0,01 & 0,02 \\
\hline Nardo-Callunetea & 0,00 & 0,00 & 0,00 & 0,00 & 0,00 & 0,00 & 0,00 & 0,00 \\
\hline Nardetalia & 0,00 & 0,00 & 0,00 & 0,00 & 0,00 & 0,00 & 0,00 & 0,00 \\
\hline Nardo-Agrostion tenuis & 0,06 & 0,04 & 0,00 & 0,00 & 0,01 & 0,00 & 0,00 & 0,00 \\
\hline Nardetalia s.l. & 0,06 & 0,04 & 0,00 & 0,00 & 0,01 & 0,00 & 0,00 & 0,00 \\
\hline Nardo-Callunetea s.l. & 0,06 & 0,04 & 0,00 & 0,00 & 0,01 & 0,00 & 0,00 & 0,00 \\
\hline Calluno-Ulicetea & 0,00 & 0,00 & 0,00 & 0,00 & 0.00 & 0.00 & 0.00 & 0.00 \\
\hline Vaccinio-Genistetalia & 0,00 & 0,00 & 0,00 & 0,00 & 0.00 & 0.00 & 0.00 & 0.00 \\
\hline Calluno-Genistion & 0,02 & 0,00 & 0,00 & 0,00 & 0.00 & 0.00 & 0.00 & 0.00 \\
\hline Vaccinio-Genistetalia s.l. & 0,02 & 0,00 & 0,00 & 0,00 & 0.00 & 0.00 & 0.00 & 0.00 \\
\hline Calluno-Ulicetea s.l. & 0,02 & 0,00 & 0,00 & 0,00 & 0.00 & 0.00 & 0.00 & 0.00 \\
\hline Molinio-Arrhenatherea s.l. & 5,08 & 3,60 & 7,71 & 4,86 & 1,03 & 1,22 & 3,33 & 1,27 \\
\hline Puccinellio-Salicornea & 0,00 & 0,00 & 0,00 & 0,00 & 0,00 & 0,00 & 0,00 & 0,00 \\
\hline Festuco-Puccinellietea & 0,15 & 0,04 & 0,74 & 0,36 & 0,02 & 0,00 & 0,17 & 0,03 \\
\hline Festuco-Puccinellietalia & 0,02 & 0,00 & 0,16 & 0,12 & 0,00 & 0,00 & 0,02 & 0,01 \\
\hline Festuco-Puccinellietea s.l. & 0,17 & 0,04 & 0,90 & 0,48 & 0,02 & 0,00 & 0,19 & 0,04 \\
\hline Puccinellio-Salicornea s.l. & 0,17 & 0,04 & 0,90 & 0,48 & 0,02 & 0,00 & 0,19 & 0,04 \\
\hline Sedo-Corynephorea & 0,00 & 0,00 & 0,00 & 0,00 & 0.00 & 0.00 & 0.00 & 0.00 \\
\hline Sedo-Scleranthetea & 0,00 & 0,00 & 0,00 & 0,00 & 0.00 & 0.00 & 0.00 & 0.00 \\
\hline Sedo-Scleranthetalia & 0,00 & 0,00 & 0,00 & 0,00 & 0.00 & 0.00 & 0.00 & 0.00 \\
\hline Alysso-Sedion & 0,01 & 0,00 & 0,01 & 0,00 & 0.00 & 0.00 & 0.00 & 0.00 \\
\hline Sedo-Scleranthetalia s.l. & 0,01 & 0,00 & 0,01 & 0,00 & 0.00 & 0.00 & 0.00 & 0.00 \\
\hline Sedo-Scleranthetea s.l. & 0,01 & 0,00 & 0,01 & 0,00 & 0.00 & 0.00 & 0.00 & 0.00 \\
\hline Sedo-Corynephorea s.l. & 0,01 & 0,00 & 0,01 & 0,00 & 0.00 & 0.00 & 0.00 & 0.00 \\
\hline
\end{tabular}


Kitaibelia 25(2): 215-238.

\begin{tabular}{|c|c|c|c|c|c|c|c|c|}
\hline & \multicolumn{4}{|c|}{ Csoportrészes edés } & \multicolumn{4}{|c|}{ 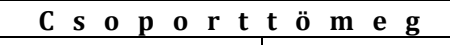 } \\
\hline & Pn Dráva & Pa Dráva & Pn Szk & PaSzk & Pn Dráva & Pa Dráva & Pn Szk & PaSzk \\
\hline Festuco-Bromea & 0,16 & 0,02 & 0,04 & 0,08 & 0,02 & 0,00 & 0,00 & 0,01 \\
\hline Festucetea vaginatae & 0,00 & 0,00 & 0,00 & 0,00 & 0,00 & 0,00 & 0,00 & 0,00 \\
\hline Festucetalia vaginatae & 0,00 & 0,00 & 0,00 & 0,00 & 0,00 & 0,00 & 0,00 & 0,00 \\
\hline Festucion vaginatae & 0,12 & 0,00 & 0,02 & 0,00 & 0,01 & 0,00 & 0,00 & 0,00 \\
\hline Festucetalia vaginatae s.l. & 0,12 & 0,00 & 0,02 & 0,00 & 0,01 & 0,00 & 0,00 & 0,00 \\
\hline Festucetea vaginatae s.l. & 0,12 & 0,00 & 0,02 & 0,00 & 0,01 & 0,00 & 0,00 & 0,00 \\
\hline Festuco-Brometea & 0,23 & 0,09 & 0,00 & 0,06 & 0,02 & 0,01 & 0,00 & 0,01 \\
\hline Festucetalia valesiacae & 0,04 & 0,00 & 0,05 & 0,00 & 0,00 & 0,00 & 0,00 & 0,00 \\
\hline Festucion rupicolae & 0,01 & 0,01 & 0,00 & 0,00 & 0,00 & 0,00 & 0,00 & 0,00 \\
\hline Cynodonto-Festucenion & 0,29 & 0,00 & 0,12 & 0,00 & 0,03 & 0,00 & 0,01 & 0,00 \\
\hline Festucion rupicolae s.l. & 0,30 & 0,01 & 0,12 & 0,00 & 0,03 & 0,00 & 0,01 & 0,00 \\
\hline Festucetalia valesiacae s.l. & 0,34 & 0,01 & 0,17 & 0,00 & 0,03 & 0,00 & 0,01 & 0,00 \\
\hline Festuco-Brometea s.l. & 0,57 & 0,10 & 0,17 & 0,06 & 0,05 & 0,01 & 0,01 & 0,01 \\
\hline Festuco-Bromea s.l. & 0,85 & 0,12 & 0,23 & 0,14 & 0,08 & 0,01 & 0,01 & 0,02 \\
\hline Chenopodio-Scleranthea & 0,98 & 0,62 & 2,48 & 0,53 & 0,23 & 1,28 & 0,25 & 0,05 \\
\hline Secalietea & 1,24 & 1,03 & 1,18 & 0,75 & 0,28 & 0,79 & 0,70 & 0,23 \\
\hline Aperetalia & 0,00 & 0,00 & 0,00 & 0,00 & 0,00 & 0,00 & 0,00 & 0,00 \\
\hline Aphanion & 0,07 & 0,00 & 0,00 & 0,00 & 0,01 & 0,00 & 0,00 & 0,00 \\
\hline Aperetalia s.l. & 0,07 & 0,00 & 0,00 & 0,00 & 0,01 & 0,00 & 0,00 & 0,00 \\
\hline Secalietalia & 0,00 & 0,00 & 0,00 & 0,00 & 0,00 & 0,00 & 0,00 & 0,00 \\
\hline Caucalidion platycarpos & 0,00 & 0,00 & 0,05 & 0,03 & 0,00 & 0,00 & 0,01 & 0,00 \\
\hline Secalietalia s.l. & 0,00 & 0,00 & 0,05 & 0,03 & 0,00 & 0,00 & 0,01 & 0,00 \\
\hline Secalietea s.l. & 1,31 & 1,03 & 1,23 & 0,78 & 0,29 & 0,79 & 0,71 & 0,23 \\
\hline Chenopodietea & 0,83 & 1,31 & 1,27 & 1,27 & 0,20 & 0,13 & 0,13 & 0,11 \\
\hline Sisymbrietalia & 0,00 & 0,00 & 0,00 & 0,00 & 0,00 & 0,00 & 0,00 & 0,00 \\
\hline Sisymbrion officinalis & 0,01 & 0,00 & 0,20 & 0,12 & 0,00 & 0,00 & 0,02 & 0,01 \\
\hline Sisymbrietalia s.l. & 0,01 & 0,00 & 0,20 & 0,12 & 0,00 & 0,00 & 0,02 & 0,01 \\
\hline Onopordetalia & 0,00 & 0,00 & 0,04 & 0,04 & 0.00 & 0.00 & 0.00 & 0.00 \\
\hline Onopordion acanthii & 0,01 & 0,00 & 0,00 & 0,00 & 0.00 & 0.00 & 0.00 & 0.00 \\
\hline Onopordetalia s.l. & 0,01 & 0,00 & 0,04 & 0,04 & 0.00 & 0.00 & 0.00 & 0.00 \\
\hline Chenopodietea s.l. & 0,85 & 1,31 & 1,51 & 1,43 & 0,20 & 0,13 & 0,15 & 0,12 \\
\hline Artemisietea & 0,00 & 0,00 & 0,00 & 0,00 & 0,00 & 0,00 & 0,00 & 0,00 \\
\hline Artemisietalia & 0,00 & 0,00 & 0,00 & 0,00 & 0,00 & 0,00 & 0,00 & 0,00 \\
\hline Arction lappae & 1,21 & 1,35 & 1,16 & 1,08 & 0,88 & 0,53 & 3,64 & 1,45 \\
\hline Artemisietalia s.l. & 1,21 & 1,35 & 1,16 & 1,08 & 0,88 & 0,53 & 3,64 & 1,45 \\
\hline Artemisietea s.l. & 1,21 & 1,35 & 1,16 & 1,08 & 0,88 & 0,53 & 3,64 & 1,45 \\
\hline Galio-Urticetea & 0,00 & 0,00 & 0,00 & 0,00 & 0,00 & 0,00 & 0,00 & 0,00 \\
\hline Calystegietalia sepium & 0,00 & 0,00 & 0,00 & 0,00 & 0,00 & 0,00 & 0,00 & 0,00 \\
\hline Galio-Alliarion & 3,77 & 4,87 & 1,65 & 2,46 & 1,35 & 1,35 & 3,69 & 1,60 \\
\hline Calystegion sepium & 3,68 & 2,86 & 7,87 & 7,15 & 1,81 & 0,64 & 6,42 & 1,66 \\
\hline Calystegietalia sepium s.l. & 7,45 & 7,73 & 9,52 & 9,61 & 3,16 & 1,99 & 10,11 & 3,26 \\
\hline Galio-Urticetea s.l. & 7,45 & 7,73 & 9,52 & 9,61 & 3,16 & 1,99 & 10,11 & 3,26 \\
\hline Bidentetea & 0,00 & 0,00 & 0,00 & 0,00 & 0,00 & 0,00 & 0,00 & 0,00 \\
\hline Bidentetalia & 0,72 & 0,74 & 2,38 & 1,33 & 0,08 & 0,08 & 0,42 & 0,14 \\
\hline Bidention tripartiti & 0,17 & 0,07 & 0,62 & 0,24 & 0,02 & 0,01 & 0,14 & 0,03 \\
\hline Bidentetalia s.l. & 0,89 & 0,81 & 3,00 & 1,57 & 0,10 & 0,09 & 0,56 & 0,17 \\
\hline Bidentetea s.l. & 0,89 & 0,81 & 3,00 & 1,57 & 0,10 & 0,09 & 0,56 & 0,17 \\
\hline Plantaginetea & 0,00 & 0,00 & 0,00 & 0,00 & 0,00 & 0,00 & 0,00 & 0,00 \\
\hline Plantaginetalia majoris & 0,35 & 0,36 & 1,18 & 0,83 & 0,04 & 0,04 & 0,22 & 0,07 \\
\hline Agropyro-Rumicion crispi & 0,00 & 0,00 & 0,03 & 0,05 & 0.00 & 0.00 & 0.00 & 0.00 \\
\hline Polygonion avicularis & 0,00 & 0,00 & 0,04 & 0,00 & 0.00 & 0.00 & 0.00 & 0.00 \\
\hline Plantaginetalia majoris s.l. & 0,35 & 0,36 & 1,25 & 0,88 & 0.00 & 0.00 & 0.00 & 0.00 \\
\hline Plantaginetea s.l. & 0,35 & 0,36 & 1,25 & 0,88 & 0,04 & 0,04 & 0,22 & 0,07 \\
\hline
\end{tabular}


KEVEY \& CSETE (2020): Feketenyár-ligetek a Dráva mentén

\begin{tabular}{|c|c|c|c|c|c|c|c|c|}
\hline & \multicolumn{4}{|c|}{ C so portré szes e d és } & \multicolumn{4}{|c|}{ 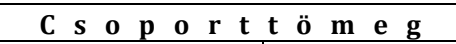 } \\
\hline & Pn Dráva & Pa Dráva & Pn Szk & PaSzk & Pn Dráva & Pa Dráva & Pn Szk & PaSzk \\
\hline Epilobietea angustifolii & 0,00 & 0,00 & 0,00 & 0,00 & 0,00 & 0,00 & 0,00 & 0,00 \\
\hline Epilobietalia & 3,14 & 4,07 & 3,84 & 5,17 & 1,54 & 3,69 & 4,92 & 2,02 \\
\hline Epilobion angustifolii & 0,45 & 0,56 & 0,00 & 0,00 & 0,05 & 0,06 & 0,00 & 0,00 \\
\hline Epilobietalia s.l. & 3,59 & 4,63 & 3,84 & 5,17 & 1,59 & 3,75 & 4,92 & 2,02 \\
\hline Epilobietea angustifolii s.l. & 3,59 & 4,63 & 3,84 & 5,17 & 1,59 & 3,75 & 4,92 & 2,02 \\
\hline Urtico-Sambucetea & 0,00 & 0,00 & 0,00 & 0,00 & 0,00 & 0,00 & 0,00 & 0,00 \\
\hline Sambucetalia & 0,00 & 0,00 & 0,00 & 0,00 & 0,00 & 0,00 & 0,00 & 0,00 \\
\hline Sambuco-Salicion capreae & 0,36 & 0,45 & 0,18 & 0,37 & 0,57 & 2,34 & 0,43 & 0,04 \\
\hline Sambucetalia s.l. & 0,36 & 0,45 & 0,18 & 0,37 & 0,57 & 2,34 & 0,43 & 0,04 \\
\hline Urtico-Sambucetea s.l. & 0,36 & 0,45 & 0,18 & 0,37 & 0,57 & 2,34 & 0,43 & 0,04 \\
\hline Chenopodio-Scleranthea s.l. & 16,99 & 18,29 & 24,17 & 21,42 & 7,06 & 10,94 & 20,99 & 7,41 \\
\hline Indifferens & 4,58 & 4,14 & 5,04 & 3,60 & 3,88 & 7,34 & 8,04 & 3,66 \\
\hline Adventiva & 10,76 & 8,55 & 10,89 & 8,84 & 5,27 & 4,47 & 11,97 & 9,64 \\
\hline
\end{tabular}

5. táblázat Karakterfajok aránya II.

Table 5 Proportion of diagnostic species II.

Vízvár FL: Vízvár „Felső-Lóka” (17213 sz. felvétel; Tengerszint feletti magasság 112 m)

Vízvár AL: Vízvár „Alsó-Lóka” (17211 sz. felvétel; Tengerszint feletti magasság 108 m)

\begin{tabular}{|c|c|c|c|c|c|c|}
\hline & \multicolumn{3}{|c|}{ Csoportrészesedés } & \multicolumn{3}{|c|}{ Csoporttömeg } \\
\hline & Vízvár FL & Vízvár AL & Asszociáció & Vízvár FL & Vízvár AL & Asszociáció \\
\hline Salicetea purpureae s.l. & 6,43 & 15,58 & 8,92 & 24,09 & 46,60 & 33,07 \\
\hline Querco-Fagetea & 8,24 & 4,80 & 9,85 & 10,19 & 2,51 & 11,47 \\
\hline Fagetalia sylvaticae & 16,37 & 4,58 & 8,63 & 37,38 & 4,31 & 15,93 \\
\hline Alnion incanae s.l. & 12,35 & 8,17 & 10,08 & 8,78 & 7,00 & 7,48 \\
\hline
\end{tabular}

6. táblázat Szociális magatartási típusok aránya

Table 6 Proportion of social behaviour types (SBT)

Pn Dráva: Carduo crispi-Populetum nigrae, Dráva-ártér (Kevey et al. ined.: 25 felv.)

Pa Dráva: Senecioni sarracenici-Populetum albae, Dráva-ártér (Kevey \& TótH 2006: 20 felv.)

Pn Szigetköz: Carduo crispi-Populetum nigrae, Szigetköz (Kevey 2008: 25 felv.)

Pa Szigetköz: Senecioni sarracenici-Populetum albae, Szigetköz (Kevey 2008: 25 felv.)

\begin{tabular}{|c|c|c|c|c|c|c|c|c|}
\hline & \multicolumn{4}{|c|}{ C soportré sze s e d és } & \multicolumn{4}{|c|}{ 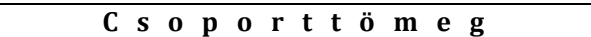 } \\
\hline & Pn Dráva & Pa Dráva & Pn Szk & Pa Szk & Pn Dráva & Pa Dráva & Pn Szk & Pa Szk \\
\hline S 6 & 4.48 & 4.36 & 2.17 & 5.63 & 1.94 & 2.97 & 0.87 & 2.11 \\
\hline C 5 & 14.42 & 10.42 & 12.42 & 12.35 & 35.94 & 32.15 & 39.13 & 43.87 \\
\hline G 4 & 32.96 & 37.93 & 23.79 & 32.29 & 39.75 & 29.82 & 9.66 & 24.94 \\
\hline NP 3 & 0.37 & 0.00 & 0.97 & 0.00 & 0.04 & 0.00 & 0.14 & 0.00 \\
\hline DT 2 & 26.60 & 31.88 & 37.02 & 34.79 & 14.32 & 26.81 & 34.59 & 18.25 \\
\hline W 1 & 6.65 & 6.41 & 8.87 & 5.63 & 2.47 & 3.73 & 3.24 & 1.15 \\
\hline I -1 & 2.24 & 1.16 & 1.21 & 1.64 & 0.39 & 0.88 & 0.61 & 0.63 \\
\hline A - 1 & 0.82 & 2.14 & 0.16 & 0.00 & 0.66 & 1.19 & 0.02 & 0.00 \\
\hline RC -2 & 2.02 & 0.45 & 3.87 & 0.47 & 0.44 & 0.04 & 0.40 & 0.04 \\
\hline AC -3 & 7.70 & 5.25 & 9.52 & 7.19 & 3.88 & 2.41 & 11.34 & 9.01 \\
\hline Val & 2.69 & 2.82 & 2.21 & 2.76 & 3.71 & 3.46 & 2.77 & 3.42 \\
\hline
\end{tabular}


7. táblázat Differenciális fajok

Table 7 Differential species

Pn: Carduo crispi-Populetum nigrae, Dráva-ártér (Kevey et al. ined.: 25 felv.)

Pa: Senecioni sarracenici-Populetum albae, Dráva-ártér (Kevey \& TóTH 2006: 20 felv.)

\begin{tabular}{|l|c|c|}
\hline & Pn & Pa \\
\hline Konstans fajok & & \\
Hedera helix & V & II \\
Populus nigra & V & II \\
Salix alba & V & III \\
Populus alba & I & V \\
Moehringia trinervia & II & V \\
Ranunculus ficaria & II & V \\
Chaerophyllum temulum & III & V \\
Geum urbanum & III & V \\
Lysimachia nummularia & III & V \\
Stellaria media & III & V \\
Szubkonstans fajok & & \\
Torilis japonica & IV & - \\
Aegopodium podagraria & IV & I \\
Aristolochia clematitis & IV & I \\
Ligustrum vulgare & IV & II \\
Carex sylvatica & I & IV \\
Physalis alkekengi & I & IV \\
Torilis japonica & I & IV \\
Viola reichenbachiana & I & IV \\
Robinia pseudo-acacia & II & IV \\
Ulmus minor & II & IV \\
\hline
\end{tabular}

\begin{tabular}{|l|c|c|}
\hline & Pn & Pa \\
\hline Akcesszórikus fajok & & \\
Impatiens glandulifera & III & - \\
Peucedanum verticillare & III & - \\
Lysimachia vulgaris & III & I \\
Phalaris arundinacea & III & I \\
Taraxacum officinale & III & I \\
Geranium robertianum & - & III \\
Aethusa cynapium & I & III \\
Cardamine impatiens & I & III \\
Carex remota & I & III \\
Echinocystis lobata adv. & I & III \\
Myosoton aquaticum & I & III \\
Paris quadrifolia & I & III \\
Rumex sanguineus & I & III \\
Szubakcesszórikus fajok & & \\
Amorpha fruticosa & II & - \\
Aster $\times$ salignus & II & - \\
Calamagrostis epigeios & II & - \\
Carex riparia & II & - \\
Dactylis polygama & II & - \\
Galium mollugo & II & - \\
Prunus spinosa & II & - \\
Rumex obtusifolius & II & - \\
Salix elaeagnos & II & - \\
Salix purpurea & II & - \\
Valeriana officinalis & II & - \\
Carex strigosa & - & II \\
Impatiens noli-tangere & - & II \\
Myosotis sparsiflora & - & II \\
\hline Differenciális fajok száma & $\mathbf{2 3}$ & $\mathbf{2 4}$ \\
\hline
\end{tabular}

